\title{
Petroleum processes in the Palaeozoic-Mesozoic strata of the Grobla-Limanowa area (basement of the Polish Carpathians)
}

\author{
Magdalena Wróbel, Paweł Kosakowski, Dariusz Więcław \\ AGH University of Science and Technology, Faculty of Geology, Geophysics and Environmental Protection; \\ al.A.Mickiewicza 30,30-059 Krakow,Poland; e-mail:wrobelm@agh.edu.pl,kosak@agh.edu.pl,wieclaw@agh.edu.pl
}

(C) 2016 Authors. This is an open access publication, which can be used, distributed and reproduced in any medium according to the Creative Commons CC-BY 4.0 License requiring that the original work has been properly cited.

Received: 31 March 2016; accepted: 1 June 2016

\begin{abstract}
The geochemical characteristics of the Palaeozoic and Mesozoic strata of the basement of the Carpathian Foredeep depicted the Devonian and Carboniferous source rocks as the best source for hydrocarbon generation. Moreover, the Outer Carpathian sequence was geochemically characterized and proved capable of generating hydrocarbons. The oil-source rocks' correlations indicated that the source of the condensate accumulated in the Łąkta field, while oil in the Grobla field. Maturity modelling identified Devonian source rocks as they reached a late phase of the "oil window" and, locally, even the "gas window". The Carboniferous source rock was mature enough to start the generation processes. The generation started in the late Carboniferous, both in the Upper Silesian and Małopolska blocks. The main phase of the petroleum processes took place in late Neogene. The expulsion was observed only in the Devonian source rocks, and vertical migration by fault system in both blocks resulted in oil and gas accumulation in the Upper Jurassic carbonates and Upper Cretaceous sandstones. The petroleum modelling indicated the Devonian source for oil and gas fields in the study area. However oil-source rock correlation also suggests the presence of the Carpathian flysch source for hydrocarbons accumulated in the Eąkta field.
\end{abstract}

Keywords: source rocks, oil-source rock correlation, Carpathian Foredeep, Mesozoic, Palaeozoic, petroleum modelling

\section{INTRODUCTION}

In the marginal region of the Upper Silesian and Małopolska blocks, several accumulations of oil and gas were found. One of them is the Grobla-Pławowice oil deposit with initial reserves of $4 \mathrm{Mt}$ (Karnkowski 1999a). The geochemistry of oils was presented by Więcław (2011) and accompanying gas by Kotarba (2012). Up-til the present, no research has unequivocally identified the source of those accumulations. Three systems containing potential source rocks were analyzed in the Limanowa-Grobla region: the Outer Carpathian, Mesozoic and upper Palaeozoic strata. The results of the geochemical analyses from the Outer
Carpathians and from the Mesozoic and Palaeozoic basement were earlier published by Kotarba et al. (2001, 2003, 2004a, 2004b), Kotarba \& Koltun (2006), Więcław et al. (2011) and Kosakowski et al. (2012). 10 oil samples used in this work were described geochemically by Więcław (2011). The 1-D and 2-D modelling were aimed to reconstruct the depositional history of the sequence of rock units and predict their behavior and petroleum properties. 1-D models were carried out in two wells, located in both tectonic blocks; the same A-A' cross-section along which the 2-D modelling was performed. The main task was to reconstruct oil and gas generation, expulsion, migration and accumulation. As a result, we determined the 
composition and amount of generated, expelled and accumulated hydrocarbons in each time period and their position in the stratigraphic profile.

\section{GEOLOGICAL SETTING}

The Palaeozoic deposits in the analyzed area between Grobla and Leśniówka belong to two regional tectonic units: Małopolska and Upper Silesian blocks (Fig. 1). The boundary between those blocks forms a narrow Kraków-Lubliniec tectonic zone (Buła 1994, 2000, Żaba 1999, Jachowicz \& Buła eds. 2010). In the development of deposits of the Palaeozoic sedimentary cover forming the Upper Silesian and Małopolska blocks, pronounced differences can be observed, which refer both to the genesis, thickness, facies variation and their lateral spreading. Those differences have already appeared in the set of deposition and lithology of the Lower Palaeozoic rocks. In the Upper Silesian

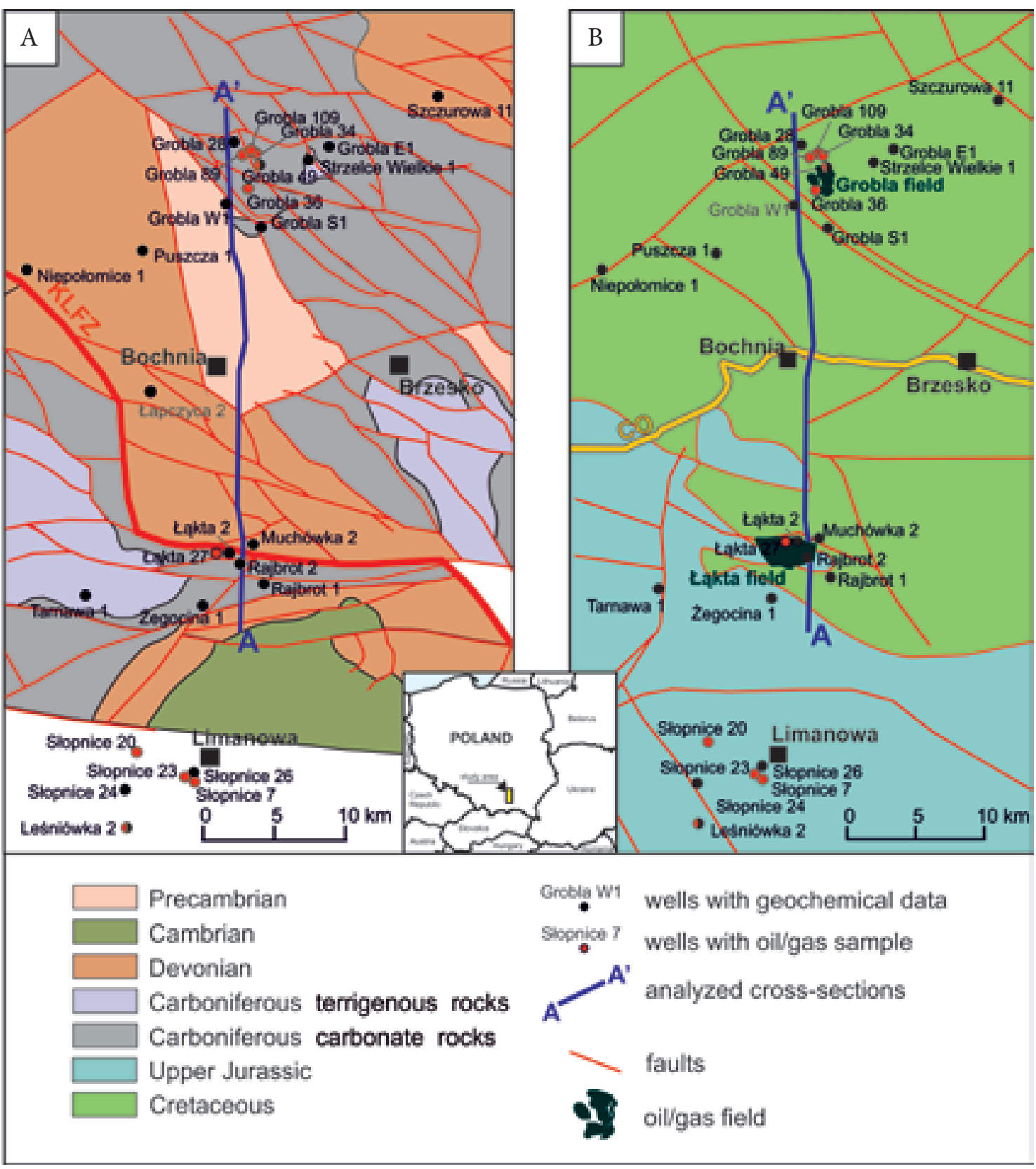

Fig. 1. Geological map of the top surface of: A) the Palaeozoic strata after Buła \& Habryn (2008, 2011); B) the Mesozoic strata after Poprawa \& Nemčok (1989) 
Block, the Lower Palaeozoic strata were characterized by a zonal distribution of the sub-Devonian surface. The oldest, Lower Cambrian strata, were found in the south-eastern and southern parts of the block, and further to the north and the northwest, the Middle Cambrian and Ordovician rocks appeared. There is no data about the presence of Silurian strata in the Upper Silesian Block (Buła \& Habryn eds. 2008, 2011).

The Lower Palaeozoic strata in the Małopolska Block do not form a continuous cover. The presence of the Cambrian clastic rocks was limited to its north and north-eastern part in the Kielce Fold Belt and Tarnogród-Lubaczów area (Buła \& Habryn eds. 2008, 2011). The litological and facial differences in the Ordovician and Silurian deposits appear in the discrepancy on older strata. They occur as isolated areas, under the cover of incomplete Devonian, Carboniferous and Mesozoic strata (Buła et al. 1997, 2002, Żaba 1999, Buła 2000, Jachowicz \& Buła eds. 2010, Buła \& Habryn 2011).

The differences were also evident in the arrangement of the Upper Palaeozoic strata. They were smaller than in the Lower Palaeozoic strata. However it is worth emphasizing the separate nature of the two blocks.

The Devonian strata on the Upper Silesian Block were represented by clastic rocks of the Lower Devonian and a carbonate complex of the Middle and Upper Devonian. Those deposits occupy the whole area of the block (Buła \& Krieger 2004). The mosaic tectonic arrangement of the basement controlled the deposition of the Devonian strata. During the whole Palaeozoic time, the uplift of the area was observed. In addtion, the thickness of the Devonian strata reached from a few dozen, in the southern part (Bielsko-Biała region), to even $1000-1500 \mathrm{~m}$, in the north-eastern part (Olkusz area) (Buła \& Habryn eds. 2008).

The Devonian strata in the Małopolska Block were recognized in more than 40 wells (Jawor \& Baran 2004, Moryc 2006, Buła \& Habryn eds. 2008). A carbonate-clastic complex could be observed there, with erosive discontinuity under the Carboniferous, Mesozoic and Miocene strata. The sedimentary profile starts with the Emsian clastic rocks in Old Red facies (Jawor \& Baran 2004). They were overlain with the Middle and Upper
Devonian carbonate rocks, up to $1000 \mathrm{~m}$ thick (Buła \& Habryn 2011).

The Carboniferous profile in the Upper Silesian Block commences with the Tournaisian-Lower-Middle Visean carbonate rocks. In the Upper Visean-Namurain A time they were replaced by the clastic deposits of the Culm facies. In the Namurian A-Westfalian time, the sedimantation of paralic and limnic coal-bearing strata developed (Kotas 1972, 1982). Locally, non-coalbearing deposits named Kwaczała arkose also occured (Rutkowski 1972).

Besides carbonates, in the Tournaisian beds of the Małopolska Block, clastic rocks occur in the top parts. The sedimentation in that block was probably finished in the earliest Namurian A. The thickness of the Carboniferous strata in the Upper Silesian Block was many times bigger than in the Małopolska Block, reaching up to 5-6 km (Kotas 1982, 1985, Buła \& Krieger 2004). The differences in the palaeogeographic-facies and palaeotectonic development of the Palaeozoic strata in both blocks were the result of development of the sedimentary basins (Buła \& Jachowicz, 1996). In the Małopolska Block, the multi-phase tectonic movements played the decisive role in the development of Palaeozoic strata occurring during or prior to sedimentation, resulting in uplifting or varied, but mostly small subsidence in various parts of the block. In the Upper Silesian Block the deposition was controlled by tectonic subsidence, increasing in the western and north-western parts (Buła \& Habryn 2011).

The best emphasized distinct tectonic development of these blocks was manifested by the Mesozoic cover. In the Upper Silesian Block, the cover was vestigial and only occurred at the eastern edge of the block. The Mesozoic strata were mainly represented by the Lower Jurassic clastic rocks, Middle and Upper Jurassic carbonate complex and Upper Cretaceous carbonates (Krajewski et al. 2011). Near Myślenice and south-east of Kraków, the Permian strata were locally found. In the Małopolska Block, the Mesozoic cover was more complete and had a broader extent. The Mesozoic strata form three complexes: the Triassic, the Middle Jurassic-Lower Cretaceous, and the Upper Cretaceous complexes. Carbonate rocks prevailed. Only the Triassic and Middle 
Jurassic strata contained clastic rocks (Krajewski et al. 2011).

The whole Palaeozoic and Mesozoic basement was covered with the Miocene clastic rocks and by Outer Carpathians in the southern parts of both blocks.

\section{CHARACTERISTICS OF SOURCE ROCKS}

Methods of the geochemical analyses of rock and oil samples were originally described in publications such as: Kotarba et al. (2001, 2003, 2004a, 2004b), Kotarba \& Koltun (2006), Więcław (2011), Więcław et al. (2011) and Kosakowski et al. (2012).

\section{Results of geochemical analysis}

83 Rock-Eval results from Outer Carpathian sequence were used for geochemical characteristic (Tab. 1, Fig. 1). 62 samples came from the Dukla Unit from Leśniówka 2, Słopnice 24 and Słopnice 26 wells, and 21 samples were taken from the Silesian Unit from Muchówka 2 and Rajbrot 1 wells (Kotarba \& Koltun (2006).
From the Palaeozoic-Mesozoic basement, 299 Rock-Eval results were used: 180 from the Upper Silesian Block and 119 results from the Małopolska Block (Tab. 2, Fig. 1). The geochemical characteristic of the Palaeozoic sequence in the Upper Silesian Block was described on the basis of 138 results from the Lower Cambrian, Middle and Upper Devonian, Lower and Upper Carboniferous, collected from the Łąkta 2, Rajbrot 1,2, Tarnawa 1 and Żegocina 1 wells. The Palaeozoic strata in the Małopolska Block were characterized based on the results of geochemical analyses of 91 results from the Lower, Middle and Upper Devonian, and Lower Carboniferous strata from the Grobla 28, Łapczyca 2, Niepołomice 11, Puszcza 1 and Strzelce Wielkie 1 wells (Tab. 2, Fig. 1) (Więcław et al. 2011).

The Middle and Upper Jurassic strata of the Upper Silesian Block were characterized by results from the Rajbrot 1, 2 and Tarnawa 1 wells. In the Małopolska Block, the Middle Jurassic strata used results from the Strzelce Wielkie 1 well and Upper Jurassic, in the Grobla W1, E1, S1 and Szczurowa 11 wells (Tab. 2, Fig. 1) (Kosakowski et al. 2012).

\section{Table 1}

Geochemical characteristics and hydrocarbon potential of the Outer Carpathian strata in the Grobla-Limanowa area

\begin{tabular}{|c|c|c|c|c|c|c|}
\hline \multirow{3}{*}{ Index } & \multicolumn{6}{|c|}{ Stratigraphy } \\
\hline & \multirow{2}{*}{\multicolumn{2}{|c|}{ Silesian Unit }} & \multicolumn{4}{|c|}{ Dukla Unit } \\
\hline & & & menilit & & other b & \\
\hline \multirow{2}{*}{ TOC [wt\%] } & 0.00 to 1.22 & (21) & 0.20 to 1.37 & (25) & 0.02 to 1.73 & (36) \\
\hline & 0.12 & (2) & 0.55 & (3) & 0.47 & (3) \\
\hline \multirow{2}{*}{$T_{\max }\left[{ }^{\circ} \mathrm{C}\right]$} & 427 to 437 & (7) & 451 to 497 & (25) & 451 to 487 & (33) \\
\hline & 429 & (2) & 461 & (3) & 456 & (3) \\
\hline \multirow{2}{*}{$\begin{array}{c}\mathrm{S}_{2} \\
\text { [mg HC/g rock] }\end{array}$} & 0.14 to 1.04 & (7) & 0.16 to 0.58 & (25) & 0.12 to 2.10 & (34) \\
\hline & 0.42 & (2) & 0.24 & (3) & 0.27 & (3) \\
\hline \multirow{2}{*}{$\begin{array}{c}\mathrm{S}_{1}+\mathrm{S}_{2} \\
{[\mathrm{mg} \mathrm{HC} / \mathrm{g} \text { rock] }}\end{array}$} & 0.16 to 1.06 & (7) & 0.25 to 0.91 & (25) & 0.20 to 4.08 & (34) \\
\hline & 0.50 & (2) & 0.38 & (3) & 0.42 & (3) \\
\hline \multirow{2}{*}{ PI } & 0.02 to 0.16 & (7) & 0.20 to 0.44 & (25) & 0.14 to 0.49 & (34) \\
\hline & 0.12 & $\overline{(2)}$ & 0.36 & (3) & 0.30 & (3) \\
\hline \multirow{2}{*}{$\begin{array}{c}\mathrm{HI} \\
{[\mathrm{mg} \mathrm{HC} / \mathrm{g} \text { TOC] }}\end{array}$} & 38 to 153 & (7) & 30 to 90 & (25) & 32 to 239 & (34) \\
\hline & 98 & (2) & 42 & (3) & 70 & (3) \\
\hline
\end{tabular}

TOC - total organic carbon; $T_{\max }$ - temperature of maximum of $\mathrm{S}_{2}$ peak; $\mathrm{S}_{2}$ - residual petroleum potential; $\mathrm{S}_{1}$ - oil and gas yield; PI - production index; HI - hydrogen index. Range of geochemical parameters is given as numerator; median values in denominator, in parentheses: number of samples from wells (numerator) and number of sampled wells (denominator). 


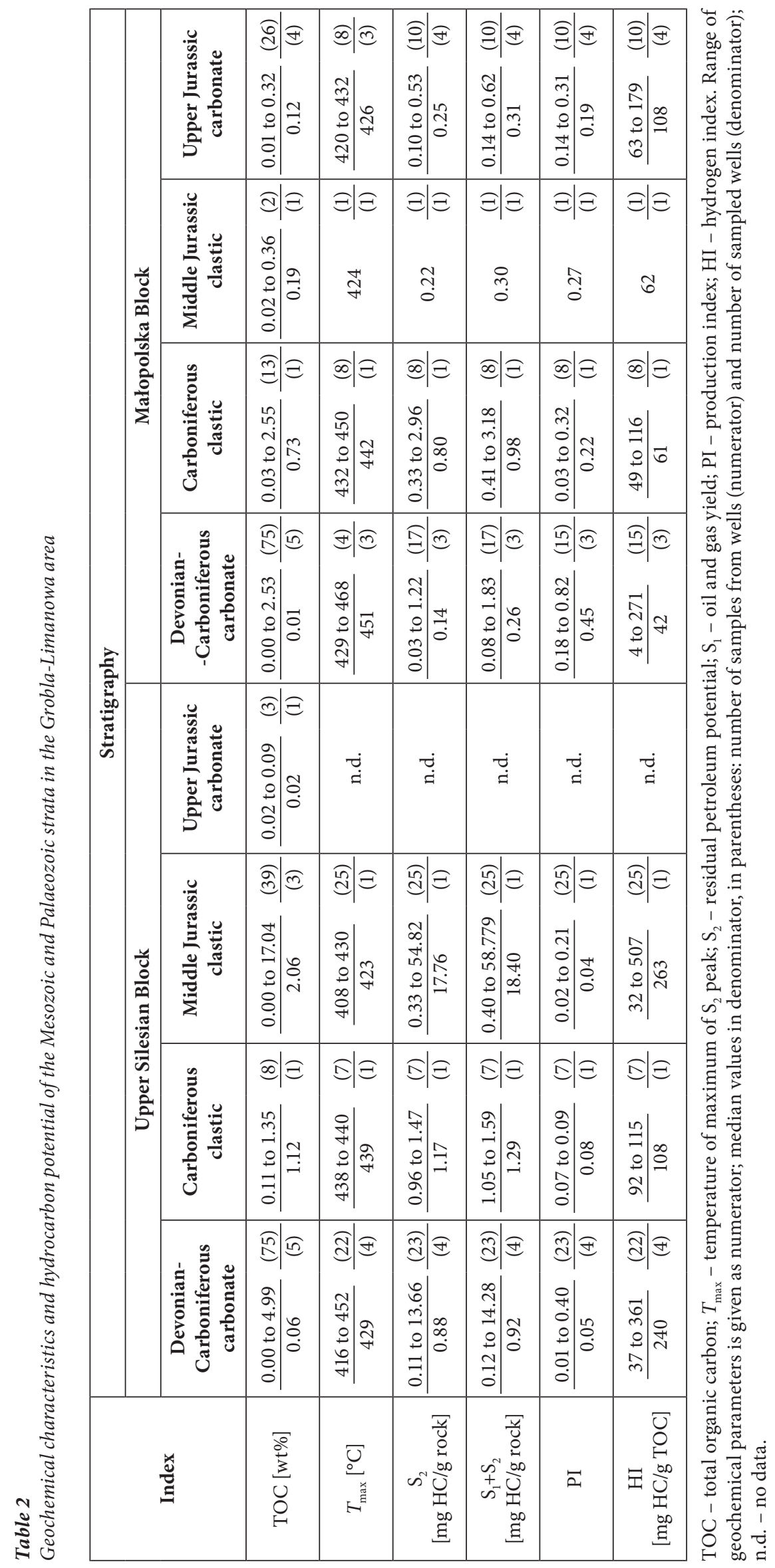




\section{Source rocks of the Outer Carpathians}

From the Outer Carpathian sequence, the Upper Cretaceous-Palaeocene Inoceramian Beds, Eocene Rdzawka Beds and Oligocene Sub-Grybów Beds, Menilite Shales and Krosno Beds from the Dukla Unit and the Lower Cretaceous Lgota Beds and Upper Cretaceous Godula Beds from the Silesian Unit were geochemically characterized (Tab. 1). As the clayey and siliceous Oligocene Menilite Shales were considered to be the primary petroleum source rock of the Carpathian oil and gas accumulations with total organic carbon (TOC) exceeding $20 \mathrm{wt} \%$ (ten Haven et al. 1993, Bessereau et al. 1996, Kotarba \& Koltun 2006, Kotarba et al. 2007, 2013, 2014, Kosakowski et al. 2009), these strata were characterised separately from other divisions of the Dukla Unit. Due to generally low TOC content in the analyzed strata of the Silesian Unit (Lgota and Godula Beds), they were characterized together (Tab. 1, Fig. 2A).

The Menilite Shales in the analyzed area had rather low organic carbon content, from $0.2 \mathrm{wt} \%$ to $1.37 \mathrm{wt} \%$, with the median of $0.55 \mathrm{wt} \%$ (Tab. 1 , Fig. 2A). The residual hydrocarbon potential was also low and never exceeded $1 \mathrm{mg} \mathrm{HC} / \mathrm{g}$ rock (Tab. 1, Fig. 2A). Similarly to the Menilite Shales,
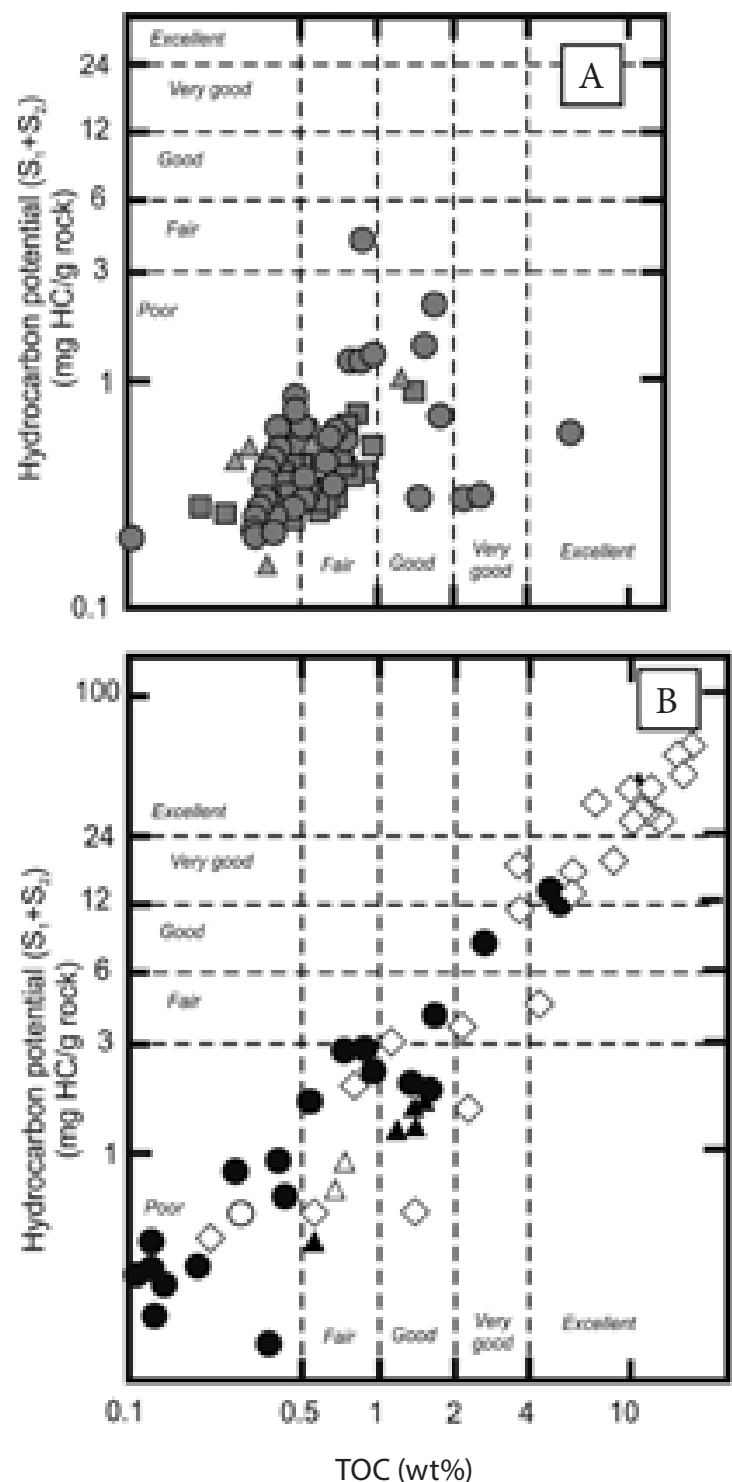
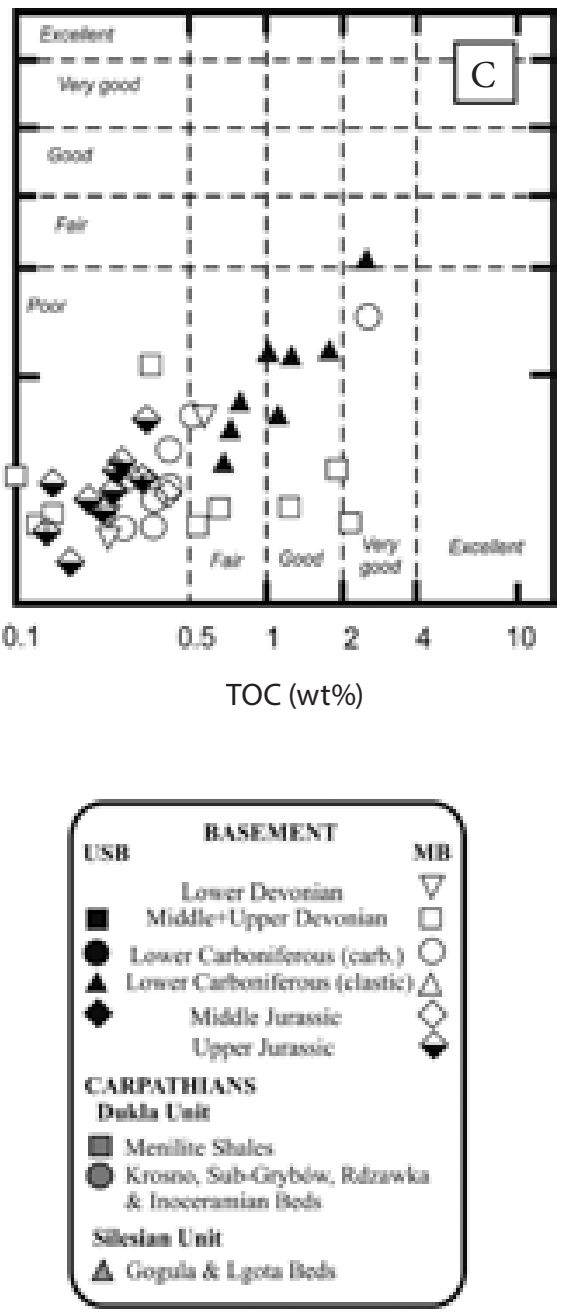

Fig. 2. Petroleum source quality diagram for organic matter dispersed in rocks from the Outer Carpathians (A), Upper Silesian Block (B) and Małopolska Block (C). Genetic classification according to Peters \& Cassa (1994) 
low TOC content prevailed in other analyzed strata of the Dukla Unit, and only for two samples, this index exceeded $1 \mathrm{wt} \%$, and the median equalled to $0.46 \mathrm{wt} \%$ (Tab. 1, Fig. 2A). The analyzed rocks from the Silesian Unit were even poorer than the above described rocks, with the TOC median of $0.12 \mathrm{wt} \%$ (Tab. 1) (Kotarba \& Koltun (2006).

The results of pyrolytic (Tab. 1, Fig. 3A), stable carbon isotope (Fig. 4) and n-alkane and isoprenoid (Fig. 5) studies revealed that mixed marine/terrestrial kerogen Type-II/III occurred in all investigated formations of the Dukla Unit.
Proportions of kerogens mixing were difficult to establish due to high maturity of organic matter dispersed in the investigated strata (Tab. 1, Fig. 3A). In the Silesian Unit sequence the gasprone Type-III kerogen was present (Fig. 3A).

The organic matter dispersed in the Silesian Unit strata was at a low maturity level (initial stage of the low-temperature thermogenic process), whereas in all analyzed strata from the Dukla Unit, the maturity corresponded with the final phase of the oil window and initial phase of the gas window (Tab. 1, Fig. 3A).
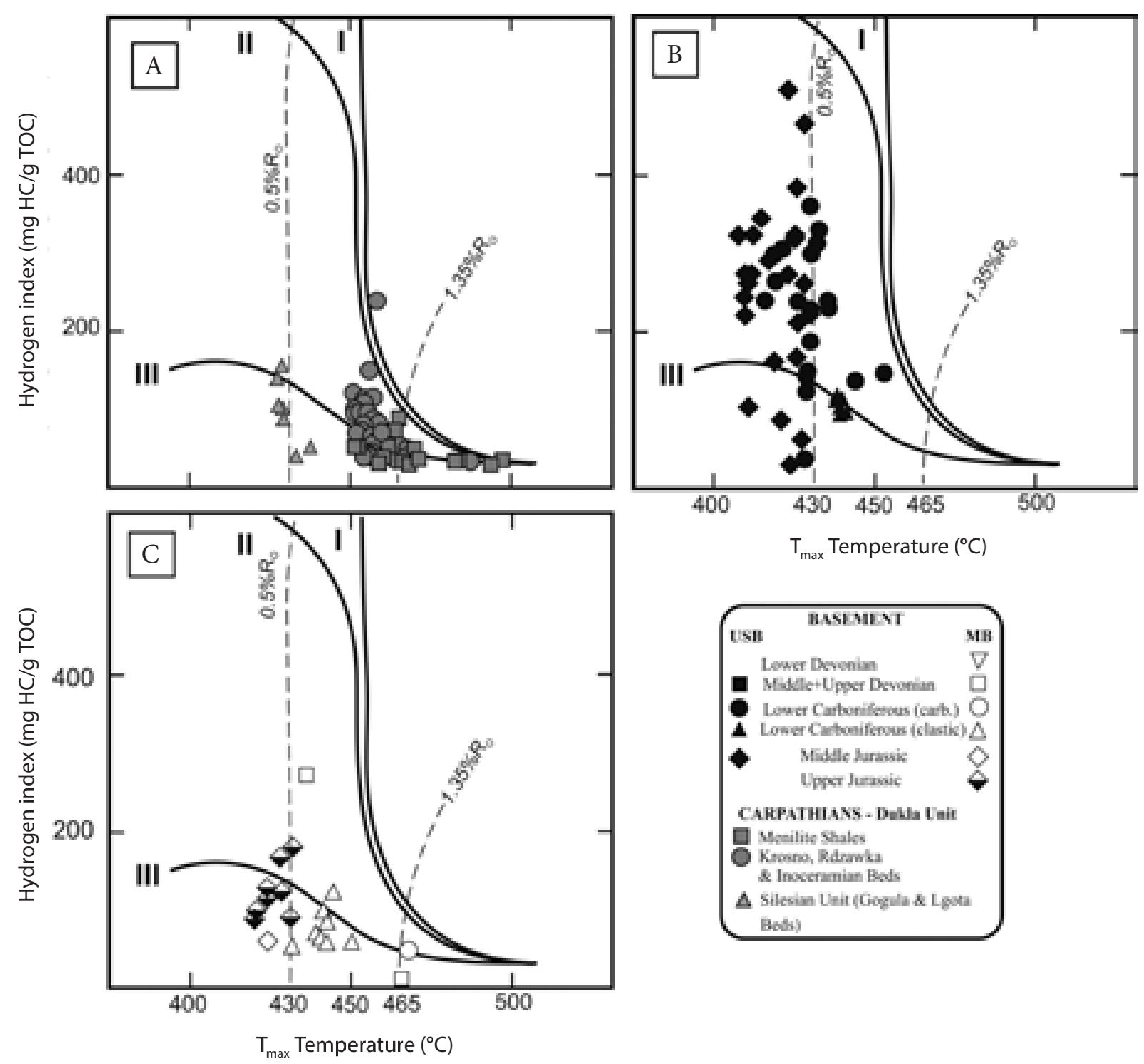

Fig. 3. Rock-Eval hydrogen index versus Tmax temperature for organic matter dispersed in rocks from Outer Carpathians (A), Upper Silesian Block (B) and Małopolska Block (C). Maturity paths of individual kerogen types according to Espitalié et al. (1985) 


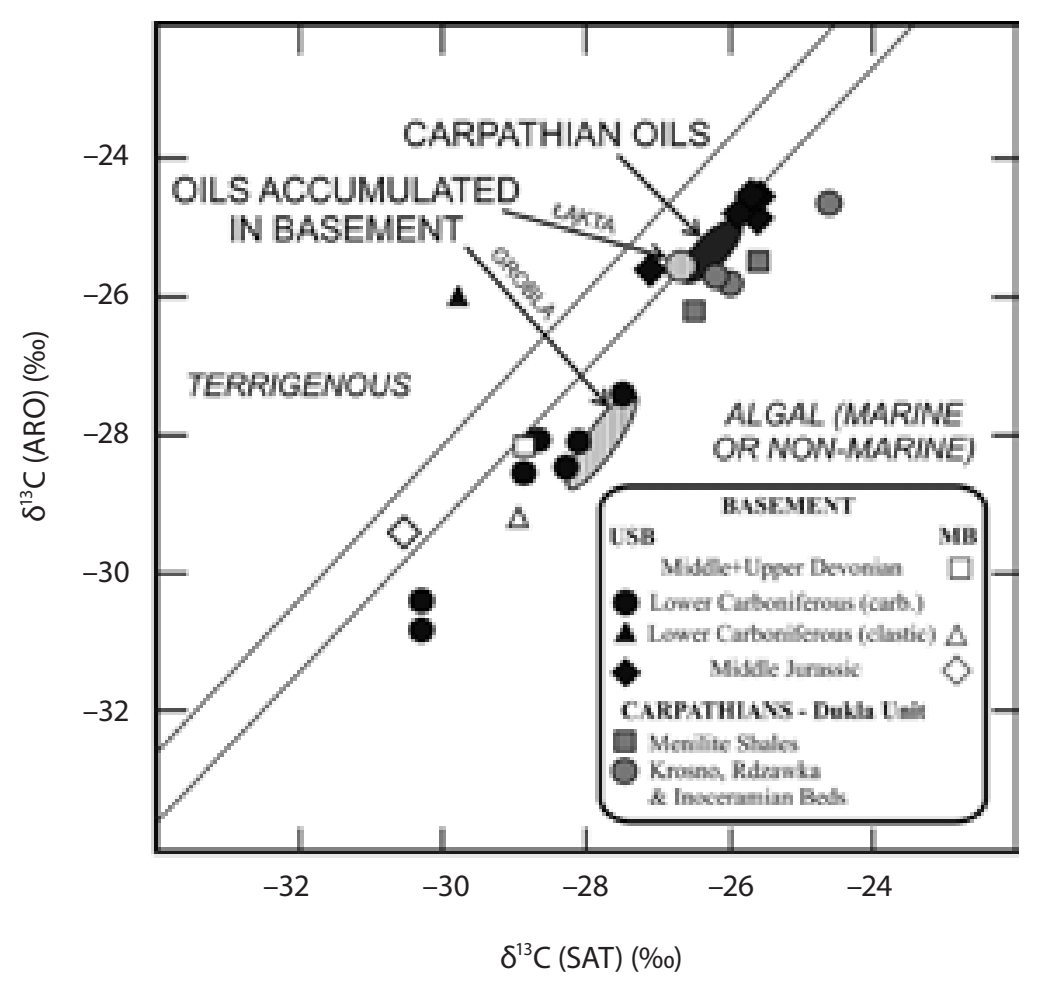

Fig. 4. Genetic characterization of bitumen and oils and source rock-oil correlation based on stable carbon isotope composition of saturated and aromatic hydrocarbons. Genetic fields according to Sofer (1984)

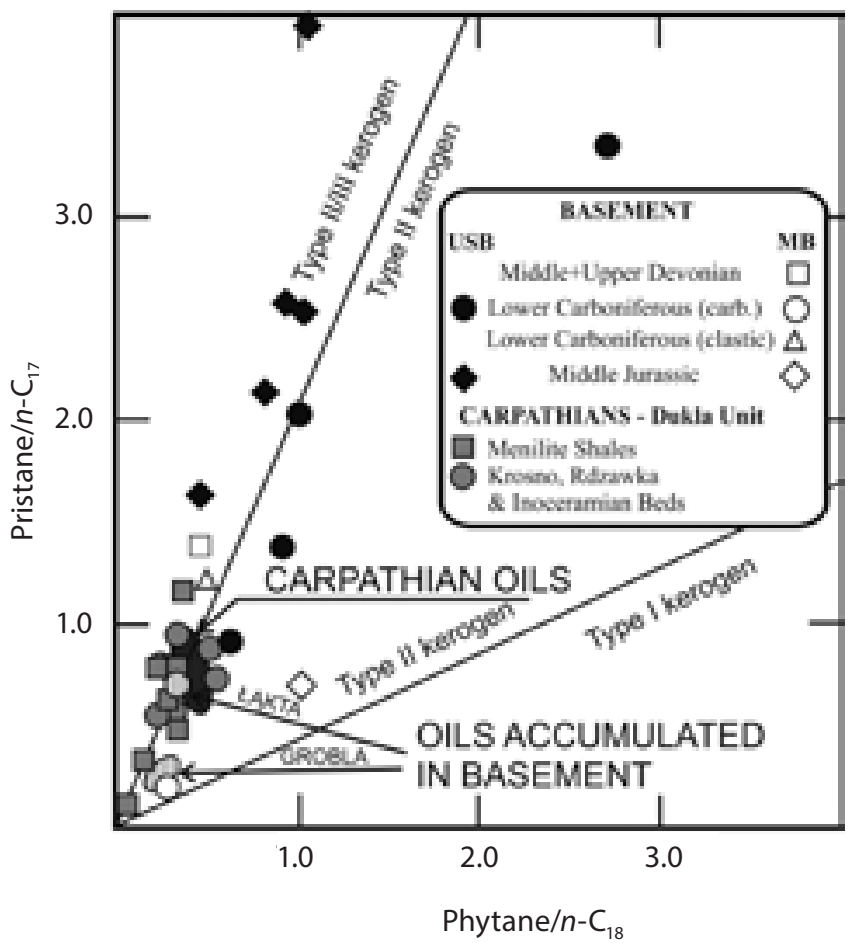

Fig. 5. Genetic characterization of bitumen and oils and source rock-oil correlation in terms of pristane/n-C17 and phytane $n-C 18$, according to the categories of Obermajer et al. (1999) 


\section{The Palaeozoic-Mesozoic source rocks in the Upper Silesian Block}

The Lower Cambrian, Middle and Upper Devonian, Lower Carboniferous (carbonate and clastic) strata were analyzed from the Upper Silesian Block Palaeozoic profile and the Middle and Upper Jurassic strata from the Mesozoic sequence (Tab. 2). The results of sample analyses were previously presented by Kotarba et al. (2001, 2003, 2004a, 2004b).

The Cambrian, Devonian and Upper Jurassic strata were lean in organic matter; TOC content never exceeded $0.5 \mathrm{wt} \%$ (Tab. 2). The carbonates of the Lower Carboniferous strata had varied organic carbon content, from $0.01 \mathrm{wt} \%$ to $5 \mathrm{wt} \%$ with median of 0.06 wt\% (Tab. 1, Fig. 2B). Low values, below $1 \mathrm{wt} \%$, dominated (Fig. 2B). Residual hydrocarbon potential resembled the TOC scatter ranging from $0.13 \mathrm{mg} \mathrm{HC} / \mathrm{g}$ rock to $13.7 \mathrm{mg} \mathrm{HC} / \mathrm{g}$ rock, with a median $0.88 \mathrm{mg} \mathrm{HC/g}$ rock (Tab. 2). This demonstrated the presence of isolated levels, with high TOC and residual hydrocarbon content (Fig. 2B). The Carboniferous clastic facies were generally good source rocks, with TOC ranging from $0.11 \mathrm{wt} \%$ to $1.35 \mathrm{wt} \%$ and median of $1.22 \mathrm{wt} \%$ (Tab. 2, Fig. 2B).

The Middle Jurassic strata were rich in organic carbon and TOC, varying from $0.00 \mathrm{wt} \%$ to $17 \mathrm{wt} \%$, with a median of $2.1 \mathrm{wt} \%$ (Tab. 2, Fig. 2B). The best source rocks were recorded in the Tarnawa 1 well profile.

The results of the Rock-Eval pyrolysis revealed the dominance of oil-prone Type-II kerogen with local admixtures of Type-III kerogen (Tab. 2, Fig. 3B). Only in the Lower Carboniferous clastic rocks, the gas-prone Type-III kerogen dominated (Fig. 3B). Stable carbon isotope composition (Fig. 4) and n-alkane and isoprenoid distribution generally confirmed pyrolytic data and indicated a high share of the terrigenous Type-III kerogen in the Middle Jurassic rocks (Fig. 5).

Pyrolytic data (Tab. 2, Fig. 3B) showed a widerange of maturity of the investigated strata: from immature to the middle phase of the oil window. The organic matter of most samples was immature or at an early-maturity stage. Only the Lower Carboniferous clastic rocks contained mature organic matter.

\section{The Palaeozoic-Mesozoic source rocks in the Małopolska Block}

The results of geochemical analyses of the Palaeozoic and Mesozoic source rocks were previously presented by Więcław et al. (2011) and Kosakowski et al. (2012). From the Palaeozoic sequence of the Małopolska Block, clastic facies of Lower Carboniferous strata had the best source rock properties. The TOC varied from $0.03 \mathrm{wt} \%$ to $2.6 \mathrm{wt} \%$ with a median of $0.73 \mathrm{wt} \%$ (Tab. 2 , Fig. 2C). Other Palaeozoic strata (the Middle and Upper Devonian and Lower Carboniferous carbonates) showed lower TOC contents, but also in those strata, intervals rich in TOC were recorded (Tab. 2, Fig. 2C). A lowered hydrocarbon potential of the Devonian carbonates, as compared to other strata, was caused by their high maturity (Tab. 2, Figs 2C, 3C). The best source rocks in the Devonian strata were recorded in the Grobla 28 well profile, where the median of TOC was $0.94 \mathrm{wt} \%$. Taking into consideration the presence of oil-prone Type-II kerogen and high maturity (gas window) of those strata, the initial organic carbon content in the discussed profile could be even twice the present value, proving the existence of a very good source rock (Peters \& Cassa 1994). Gas-prone Type-III kerogen dominates in other discussed source rocks, and admixtures of oil-prone Type-II kerogen occur sporadically (Tab. 2, Figs 3C, 4, 5).

From the Mesozoic basement, Middle and Upper Jurassic strata were characterized. Hydrocarbon potential of these rocks was low, and TOC never exceeded $0.5 \mathrm{wt} \%$ (Tab. 2, Fig. 2C). The results of Rock-Eval pyrolysis (Tab. 2, Fig. 3C), stable carbon isotope composition (Fig. 4) and biomarker distribution (Fig. 5) indicated dominance of mixed, Type-III/II kerogen. The Middle and Upper Jurassic strata were immature or at an early stage of low-temperature thermogenic processes (Tab. 2, Fig. 3C).

\section{CHARACTERISTIC OF OILS}

Four oil samples from the Upper Cretaceous-Oligocene sandstones in the Dukla Unit were collected from the Leśniówka 2, Słopnice 7, 20 and 23 wells (Fig. 1). Six oil samples were collected from the Mesozoic basement, including five samples from the Grobla 34, 36, 49, 89 and 109 wells 
from sandstone reservoirs in the Upper Cretaceous strata, and one sample from the Eąkta 27 well, from the Upper Jurassic carbonates (Fig. 1). The geochemical data for most of the Carpathian oils and part of the Mesozoic oils were taken from ten Haven et al. (1993). Geochemical characterization of oils collected from Grobla 36, 89 and 109 wells was provided by Więcław (2011).

Three populations of oils were recorded in the analyzed area. The first one consisted of oils accumulated in the Outer Carpathian sequence (Słopnice deposit and oil inflow in Leśniówka 2 well). The second one formed condensate accumulated in the Upper Jurassic carbonates in the Łąkta deposit, and the third one, oils collected from the Grobla deposit, accumulated in the Upper Cretaceous sandstones (Fig. 1).

The stable carbon isotope composition and $n$-alkane and isoprenoid distribution revealed that hydrocarbons collected from the Słopnice and Łąkta deposits had very similar characteristics (Figs 4,5). They were generated by the same source rock, or separate rocks having a very similar signature. Oils accumulated in the Grobla deposit were generated from another source rock. All analyzed liquid hydrocarbons were generated mainly from oil-prone Type-II kerogen. The source organic material of the oils accumulated in the Carpathian sequence and Łąkta deposit was of marine-terrigenous origin deposited in sub-oxic conditions (Fig. 6), whereas oils from the Grobla deposit were generated from Type-II kerogen deposited in anoxic conditions (most probably in carbonates, Figs 4, 5). The detailed determination of organic matter type and its sedimentary environment was difficult due to the high maturity level of analyzed oils (ten Haven et al. 1993, Więcław 2011).

\section{OIL-SOURCE ROCK CORRELATION}

The oil and source rock were correlated using the stable carbon isotope composition (Fig. 4) and $n$-alkane and isoprenoid distribution (Fig. 5).

Geochemical data revealed that oils accumulated in the Outer Carpathians strata (Słopnice deposit and Leśniówka 2 well) were generated from the Menilite Shales deposited in the Dukla Unit sequence (Figs 4, 5). A very good isotopic correlation of the Middle Jurassic strata with these oils (Fig. 4) was not supported by the results of other analyses. The maturity of those strata was too low for generation of oils. Probably, the same origin had a condensate accumulated in the Eąkta deposit (Figs 4, 5). Sourcing of this condensate (and gas in this deposit) cannot be excluded from deep buried Palaeozoic rocks. However, poor drilling (and sampling) of these strata made precise indication of most probable source rock levels impossible.

Oils from the Grobla deposit had another source. They were generated most probably from the Middle and Upper Devonian and Lower Carboniferous carbonates (Figs 4, 5). As an additional source, the Lower Carboniferous clastic facies can be considered (Fig. 4). The Middle Jurassic source rocks do not correlate with them (Figs 4, 5). Also, sourcing of those oils from Menilite source rocks, as proposed by ten Haven et al. (1993), based on stable isotope composition (Fig. 4), has to be excluded.

\section{PETROLEUM MODELLING}

The principal aim of the numerical modelling was to determine the depth and timing of hydrocarbon generation and expulsion processes for two wells and one cross-section located in the Upper Silesian and Małopolska blocks (Fig. 1). Burial history, hydrocarbon generation, expulsion, migration and accumulation processes were reconstructed by means of the BasinMod $^{\text {Th }} 1-\mathrm{D}$ and 2-D computer modelling software (BMRM 2006).

\section{Modelling methodology}

To assess the amount of hydrocarbons generated and expelled from the upper Palaeozoic source rocks, the following data was quantified: event definition (deposition, erosion, hiatus or non-deposition), present and original thickness, lithology of strata, and present and palaeo-heat flows. Input parameters for the modelling include geochemical data such as reconstructed TOC and genetic type of kerogen. Maturity was calculated using the EASY\%Ro model (Sweeney \& Burnham 1990), whereas for the modelling of hydrocarbon generation and expulsion, the LLNL model (BMRM 2006) was applied. The maturity modelling was calibrated with Rock-Eval $T_{\max }$ temperature and vitrinite reflectance $R_{o}$ (Więcław et al. 2011, Kosakowski et al. 2012). 


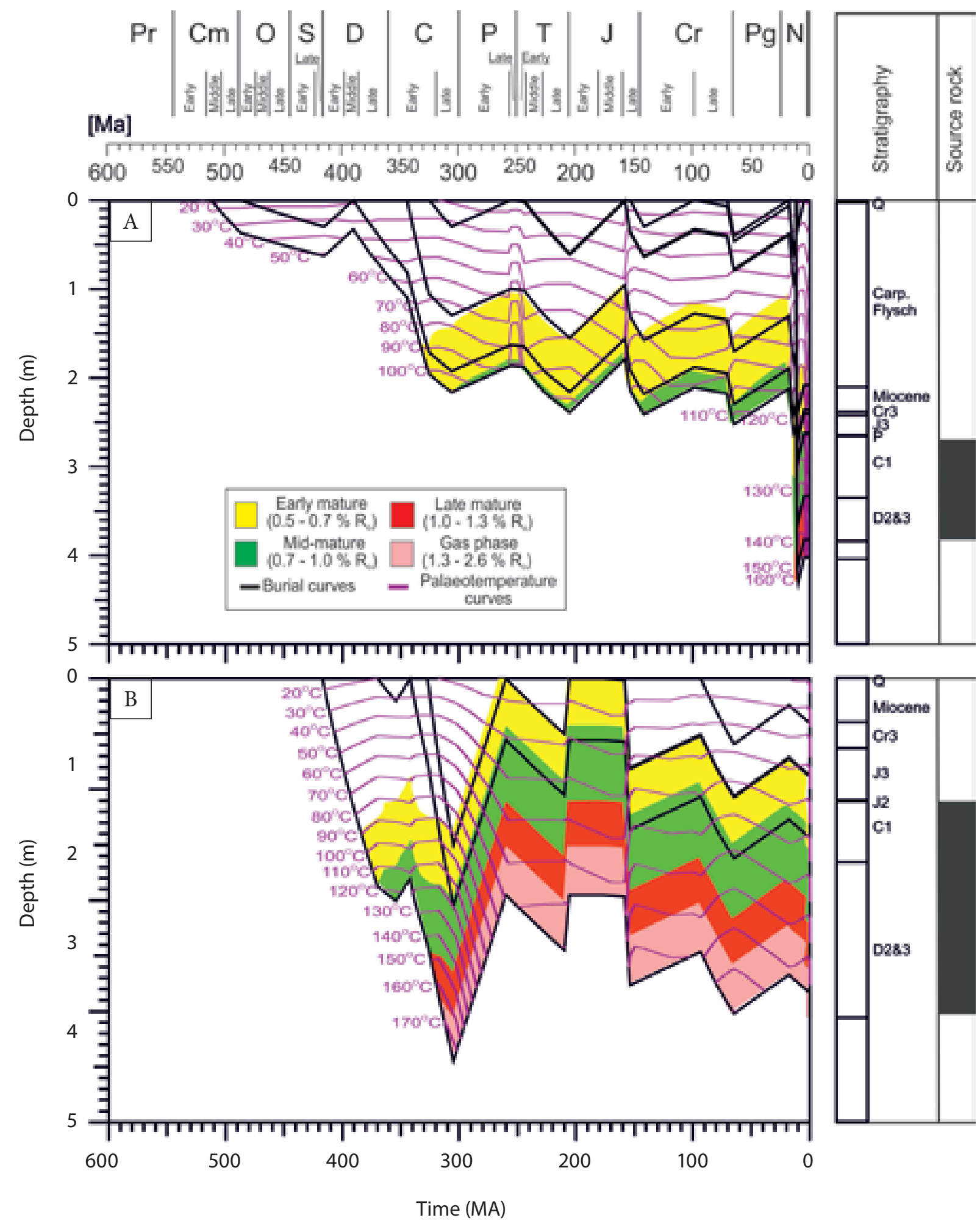

Fig. 6. Burial history curves of (A) Rajbrot 2 and (B) Grobla 28 wells. Pr-Precambrian, Cm-Cambrian, O-Ordovician, S-Silurian, D - Devonian, D2\&3 - Middle and Late Devonian, C - Carboniferous, C1 - Early Carboniferous, P - Permian, T - Triassic, J-Jurassic, J2 - Middle Jurassic, J3 - Late Jurassic, Cr - Cretaceous, Cr3 - Late Cretaceous, Pg-Paleogene, N-Neogene, Q- Quarternary, Carp. - Carpathian 
Calculation of petroleum processes such as permeability of each stratigraphic period influencing the expulsion and migration were defined by available in BasinMod software methods (BMRM 2006). Power law was applied to the analysed 2-D model for permeability calculation, with pressure as a variable of expulsion and steady state migration. Applied pressure as a force determining expulsion was determined by the Carpathian overthrust, which significantly affected the hydrocarbon movements (BMRM 2006).

The petroleum modelling was carried out in two wells profile, one in the Upper Silesian Block (Rajbrot 2) and second (Grobla 28) in Małopolska Block and along A-A' cross-section. The A-A' cross-section was $44.5 \mathrm{~km}$ long and enclosed both tectonic blocks (Fig. 1). The seismic interpretation provided basic stratigraphic horizons starting from the Precambrian, above it the Cambrian, Devonian, Carboniferous, Upper Jurassic, Upper Cretaceous, Miocene anhydrite and the bottom of Carpathian Flysch. Litological characteristics of each geological strata were describe as a percentage of particular types of rocks based on Buła \& Jachowicz (1996), Buła \& Krieger (2004), Buła \& Habryn (2011), Kotarba et al. (2011), Krajewski et al. (2011).

Two source rocks were assigned in petroleum modelling: the Middle and Upper Devonian and Lower Carboniferous carbonate series, and clastic series of the Lower Carboniferous (Tab. 3).

\section{Table 3}

Source rocks features used in petroleum models: USB - Upper Silesian Block, MB - Małopolska Block

\begin{tabular}{|l|c|c|c|c|c|c|}
\hline \multirow{2}{*}{ Source rocks } & \multicolumn{2}{|c|}{ TOC [wt\%] } & \multicolumn{2}{c|}{ Kerogen type } & \multicolumn{2}{c|}{ Thickness [m] } \\
\cline { 2 - 7 } & USB & MB & USB & MB & USB & MB \\
\hline $\begin{array}{l}\text { Devonian and Lower } \\
\text { Carboniferous carbonates }\end{array}$ & 0.5 & 1.5 & II & II & 100 & 150 \\
\hline $\begin{array}{l}\text { Lower Carboniferous } \\
\text { elastics }\end{array}$ & 1.5 & 1.2 & III & III & 100 & 100 \\
\hline
\end{tabular}

\section{Modelling of the thermal and burial history}

1-D maturity modelling of the thermal and burial history reconstruction was conducted in the Rajbrot 2 and Grobla 28 wells (Fig. 1). The model of recent thermal regime was calibrated with either well temperature logs or/and indirectly with data obtained from maps of temperatures at given depth horizons from the investigated or adjacent areas (Jurkiewicz \& Szczerba 1976, Majorowicz \& Plewa 1979, Majorowicz 1984, Plewa 1994, Karwasiecka \& Bruszewska 1997). These authors presented different values of the heat flow or temperatures, therefore, average values were used, calibrated in the process of creating a conceptual model. The values of recent heat flow, adopted for generation modelling, varied across the analyzed area from ca. $60 \mathrm{~mW} / \mathrm{m}^{2}$, in its southern and central part, to ca. $50 \mathrm{~mW} / \mathrm{m}^{2}$, in the northern part. The distribution of the recent heat flow showed a strict relationship with the extent of the major tectonic structures of the Upper Silesian and Małopolska blocks. A gradual decrease in the value of the heat flow could be observed, from the average $70 \mathrm{~mW} / \mathrm{m}^{2}$ in the Silesian block, to ca. $50 \mathrm{~mW} / \mathrm{m}^{2}$ in the contact zone of the Upper Silesian and Małopolska blocks (Majorowicz \& Plewa 1979, Belka 1993a, 1993b, Karwasiecka 2001, Kotarba et al. 2004c). That relationship also had an impact on the value of the palaeoheat flow in the Palaeozoic structural and overlying stages.

Models presented by Narkiewicz $(2002,2007)$ and Poprawa (2006a, 2006b) did not predict significant thermal events during the Cambrian-Lower Devonian time. At the Variscan stage of development of the basin, a general assumption was made of orogen overheating. That assumption was compatible with the research of Majorowicz (1984). During the Permian, Mesozoic and Cenozoic time, constant heat flow was applied (Karnkowski 1999b, Narkiewicz et al. 2010).

The deposition of Palaeozoic and Mesozoic strata was also interrupted by periods of uplifting and erosion. The periods were clearly present, especially in the late Carboniferous, early 
Jurassic, early Cretaceous, and at the turn of the Cretaceous. The maturity of the lower Palaeozoic source rocks had been strongly influenced by the early Carboniferous deposition. The late Carboniferous erosion was estimated from a few hundred meters, in the Upper Silesian Block, up to even $1500 \mathrm{~m}$ in the Małopolska Block (Fig. 6A, B). During further periods of erosion, only small changes in the maturity of the organic matter of the lower Palaeozoic source rocks were observed. The Permian and Triassic deposition thickness was assumed at $500 \mathrm{~m}$. The Upper Jurassic and Upper Cretaceous erosion events removed $300-400 \mathrm{~m}$. The last and the most important thermal - burial impulse was the Outer Carpathian overthrust on the foreland (especially in the Upper Silesian Block). It resulted both in an increase in the depth of the burial and in its temperature, and, consequently, towards the end of the stage of the Carpathian orogenic overthrust, also in an increase in organic matter maturity (Fig. 6A).

The thermal modelling carried out in the Rajbrot 2 well, with the thermal model assuming the Variscan overheating and with the assumed values of erosion, showed that the Devonian and Carboniferous source rock complexes reached the early stage of thermal maturity $\left(0.5-0.7 \% R_{o}\right)$ in the Carboniferous (Fig. 6A). The deposition of the lower Cretaceous strata caused an insignificant growth in the maturity of the organic matter (Fig. 6B). Another impulse, which resumed the process of burial of the source rock horizon, was the deposition of the Miocene and the process of Carpathian overthrust. Particularly, the latter event caused a significant growth of the burial depth of the Devonian and Carboniferous strata from ca. $2500 \mathrm{~m}$, at the beginning of the Miocene deposition, to over $4000 \mathrm{~m}$ at the end of the orogenic stage of the Carpathian overthrust (Fig. 6A). This resulted in a growth of organic matter maturity in the Devonian and Carboniferous source rocks to ca. $1.2 \%$ and $0.9 \% R_{o}$, respectively (Fig. 7).

The growth of the maturity in the Grobla 28 well profile took place only during the late Devonian and Carboniferous time (Fig. 6B). The Variscan overheating and about $1500 \mathrm{~m}$ thickness of deposited strata led to the Devonian source rock in the late Palaeozoic reaching the late phase of the "oil window", and in the bottom even reaching the "gas window" $\left(1.7 \% R_{o}\right)$ (Fig. 7). The maturity of the Carboniferous source rock did not exceed $0.8 \% R_{o}$ (Fig. 7).

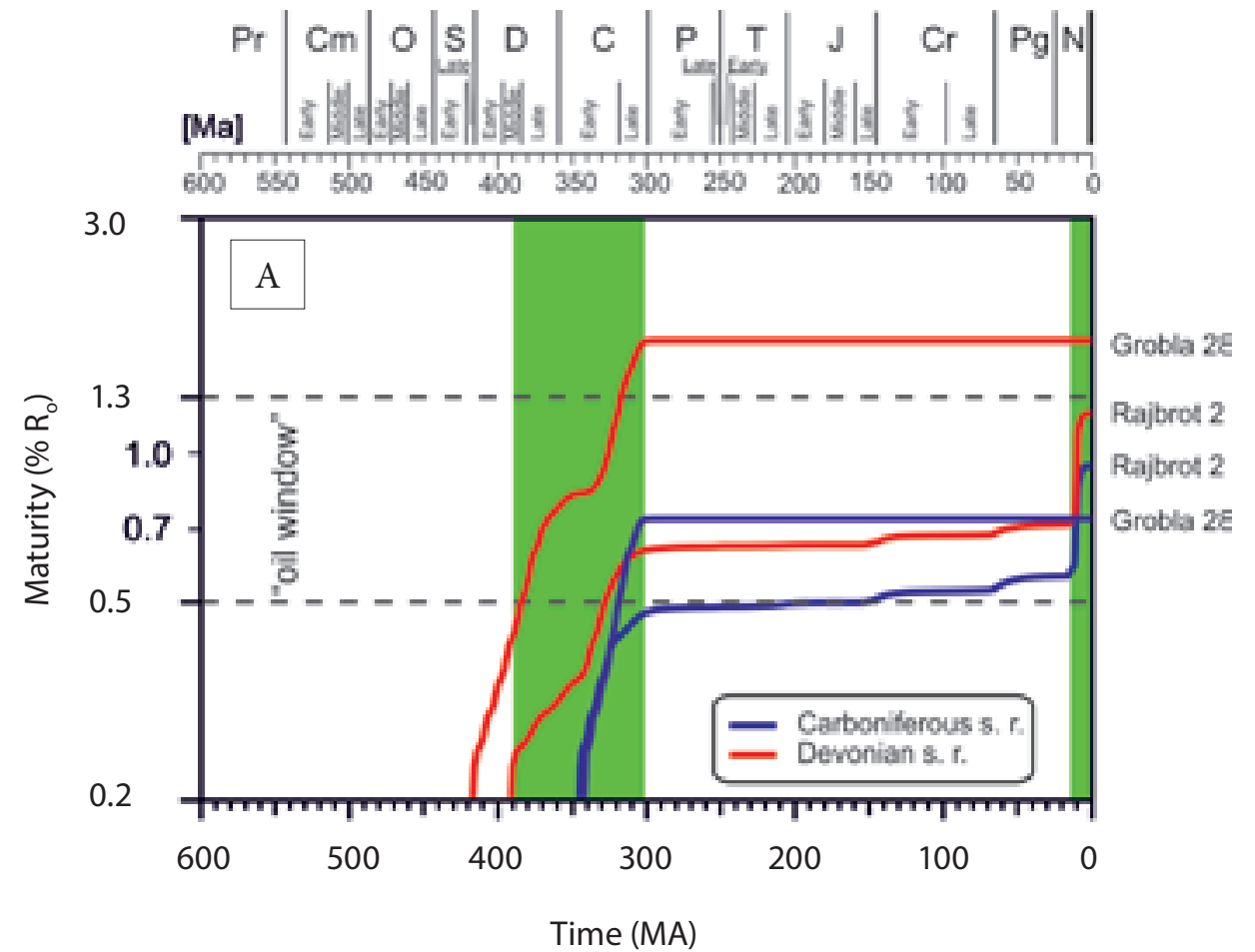

Fig. 7. Maturity evolution curves for late Palaeozoic source rocks in profiles of analysed wells: s. r. - source rocks. For abbreviations see Figure 7 


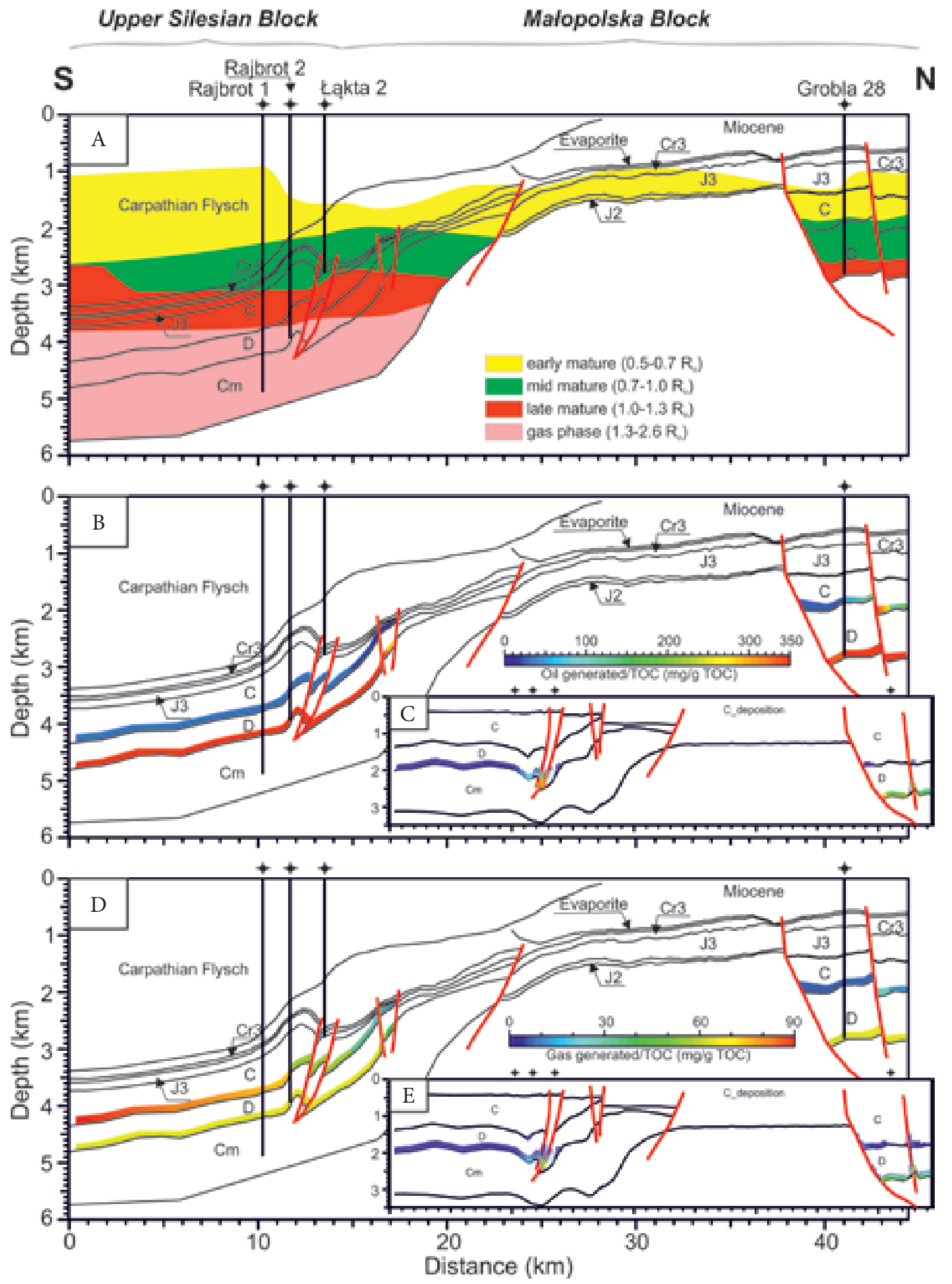

Fig. 8. Maturity schedule along the A-A'cross-section (A) and amount of generated oil therein at present (B) and after the Lower Carboniferous deposition (C) as well as amount of generated gas at present $(D)$ and after the Lower Carboniferous deposition (E) along the A-A' cross-section. Cr-Cretaceous, Cr3 - Upper Cretaceous, Cr1 - Lower Cretaceous, J3 - Upper Jurassic, J2 - Middle Jurassic, T-Triassic, C - Carboniferous, D - Devonian, $S$ - Silurian, O - Ordovician. Some of the wells were projected into cross-sections. For details see Figs 1, 2 
The present view on the maturity model along the A-A' cross-section showed that Devonian and Carboniferous source rocks were more mature in the Upper Silesian Block, where the maturity of the source rocks reached the gas phase $\left(1.3-2.6 \% R_{o}\right)$ and was caused mainly by the Carpathian overthrust, while in the Małopolska Block, the maturity ranged from the early to late phase of the "oil window" $\left(0.5-1.3 \% R_{o}\right)$ (Fig. $8 \mathrm{~A}$ ).

\section{Reconstruction of petroleum processes}

The maturity obtained by analyzed source rocks was sufficient to begin the generation processes. The transformation ratio differed in the Upper Silesian and Małopolska blocks.

The source rocks in the Rajbrot 2 well (Upper Silesian Block) were successively transformed during the Permian and Mesozoic times, though the Carpathian Overthrust caused the biggest change. The Devonian source rock was transformed 100\% and the Carboniferous source rock, 90\% (Fig. 9).

In the Małopolska Block, the transformation process occurred from the late Devonian to the end of the Carboniferous. In the Grobla 28 well, the Devonian kerogen also was totally transformed, while the Carboniferous source rock was transformed only $30 \%$ (Fig. 9).

The 2-D modelling of the generation of the hydrocarbons revealed that the Devonian and Carboniferous source rocks were the main sources of hydrocarbons occurring in the Mesozoic reservoirs in the analysed area (Fig. 8B, D).

The generation processes from Devonian source rocks in the Upper Silesian Block started in the late Carboniferous (Fig. 8C, E), but the main phase of oil and gas generation from that source horizon occurred in the Palaeogene and, especially, in the Neogene. In that tectonic Block, generation of hydrocarbons from the Carboniferous source rock took place during the late $\mathrm{Neo}-$ gene time.

In the Małopolska Block, the hydrocarbon generation had two time phases. The first phase occurred during the late Carboniferous deposition, when only the Devonian source rocks started the process of hydrocarbon generation (Fig. 8C, E). At that stage, $70 \%$ of hydrocarbon was generated from the Devonian source rocks. The second phase took place in the Miocene and enclosed the Devonian and Carboniferous source rocks.

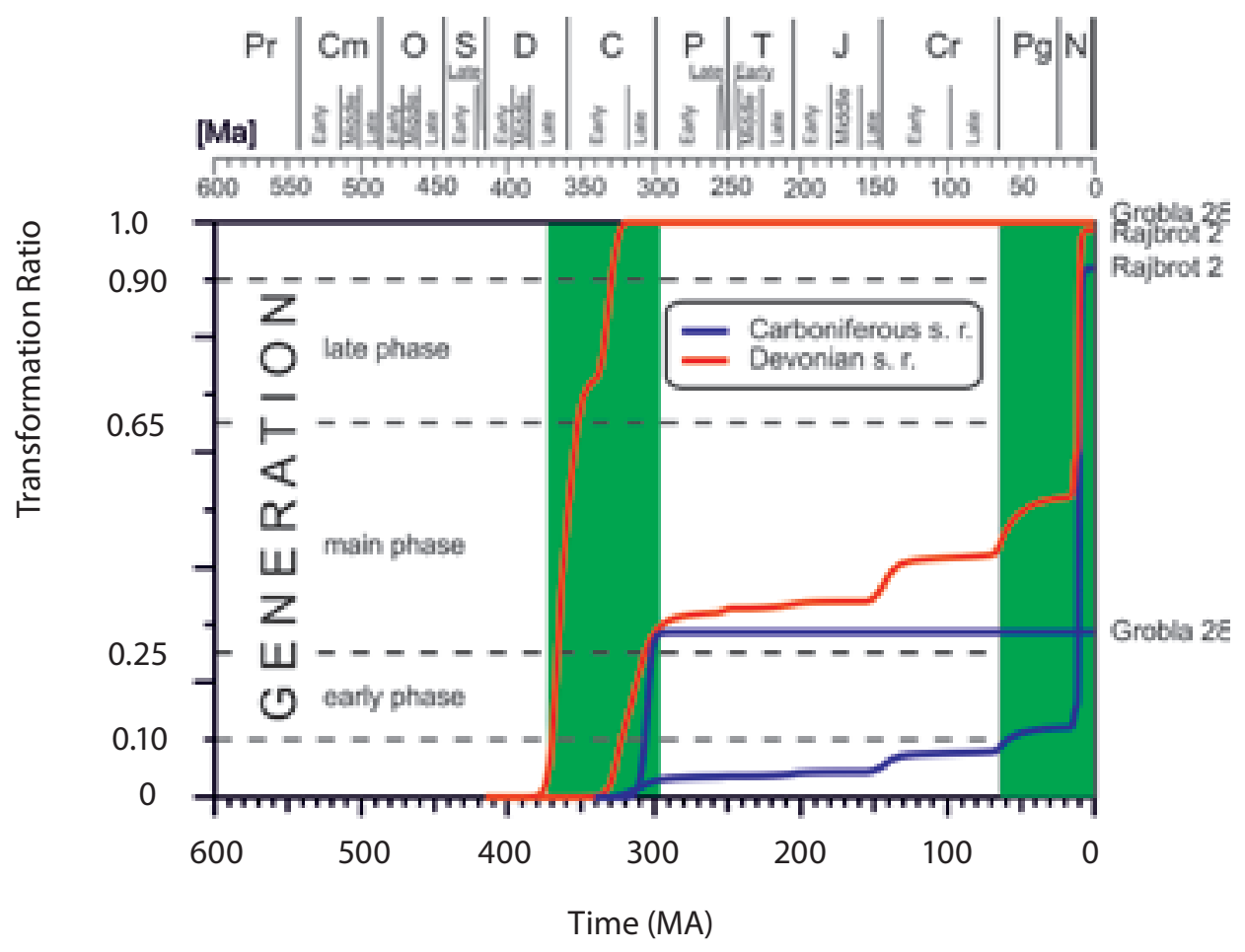

Fig. 9. Transformation ratio of kerogen in the late Palaeozoic source rocks in profiles of analysed wells. For abbreviations see Figs 7,8 
The amount of generated hydrocarbons from the Devonian source rock was $350 \mathrm{mg} / \mathrm{g}$ TOC of oil and about $70 \mathrm{mg} / \mathrm{g}$ TOC of gas (Fig. 8B, D). The volume of generated oil from the Carboniferous source horizon differed in each of the tectonic blocks, reaching $100 \mathrm{mg} / \mathrm{g}$ TOC in the Upper Silesian Block, and ranging from $100 \mathrm{mg} / \mathrm{g}$ TOC to $200 \mathrm{mg} / \mathrm{g}$ TOC in the Małopolska Block (Fig. 8B). The volume of gas generated from Carboniferous source rocks ranged from $20 \mathrm{mg} / \mathrm{g}$ TOC in the Małopolska Block, to $90 \mathrm{mg} / \mathrm{g}$ TOC in the Upper Silesian Block (Fig. 8D).

The expulsion processes occurred almost exclusively in the Devonian source rock. The expulsion processes similar to generation occurred in two phases.

In the Upper Silesian Block, the expulsion from the Devonian source rock started in the Mesozoic, precisely in the late Cretaceous. The Carpathian overthrust had a particular influence on the expulsion in that tectonic Block. During the late $\mathrm{Ne}$ ogene, a $50 \%$ increment of expelled oil and gas was observed. The maximum volume of the oil and gas expulsion from the Devonian source rock was equal to $0.007 \mathrm{~m}^{3} / \mathrm{m}^{3}$ rock and $0.0015 \mathrm{~m}^{3} / \mathrm{m}^{3}$ rock, respectively (Fig. 10A, B).

In the Małopolska Block, the expulsion from the Devonian source rock started in the late Carboniferous. Until the end of the Variscan erosion, $0.01 \mathrm{~m}^{3} / \mathrm{m}^{3}$ rock of oil and $0.002 \mathrm{~m}^{3} / \mathrm{m}^{3}$ rock of gas were expelled. This represented $50 \%$ of all hydrocarbons expelled from that source horizon. The second phase took place in the Neogene, during the Miocene deposition. The volume of expelled hydrocarbon reached $0.02 \mathrm{~m}^{3} / \mathrm{m}^{3}$ rock of oil and $0.0035 \mathrm{~m}^{3} / \mathrm{m}^{3}$ rock of gas (Fig. 10A, B).

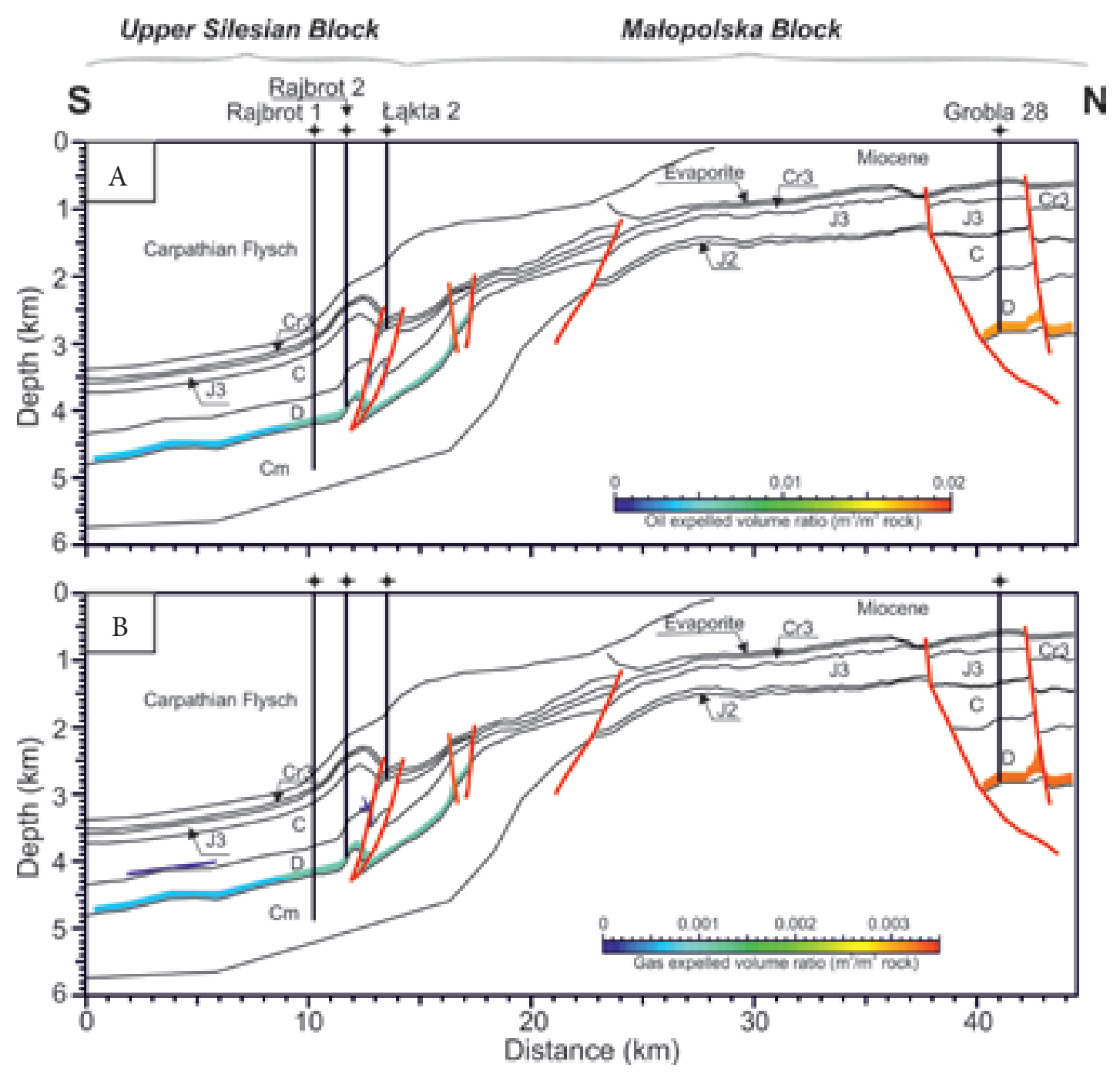

Fig. 10. The volume of the oil (A) and gas (B) expulsion along the A-A'cross-section. For abbreviations see Figure 10 
Migration of hydrocarbons was strictly connected with the fault systems. The hydrocarbon accumulations take place mainly in structural and stratigraphic traps (Myśliwiec et al. 2006). The migration paths from source rock to the reservoir were mainly vertical by faults. The reservoirs were the Upper Jurassic carbonates and the Upper Cretaceous sandstones. The combination traps (structural-stratigraphic) were located in the massive erosional or tectonic blocks of the basement carbonates and clastic, stratigraphically sealed by the shaly Miocene deposits, along the sub-Miocene unconformity or by the marly Senonian-Turonian deposits.
The Upper Jurassic (Oxfordian) carbonate reservoir was microfactured and fractured, and the horizons were separated by marlstones. The Upper Cretaceous (Cenomanian) sandstones were very good-quality, with primary porosity reaching $30 \%$ and permeability even about $260 \mathrm{mD}$ (Florek et al. 2006, Myśliwiec et al. 2006). 2-D modelling of hydrocarbon migration and accumulation revealed that migration and accumulation of hydrocarbons took place mainly during the Carpathian overthrusting in both Upper Silesian and Małopolska blocks (Figs 11A, B, 12A, B). However, in the Małopolska Block, the migration to the Mesozoic reservoirs started earlier, during the Eocene.

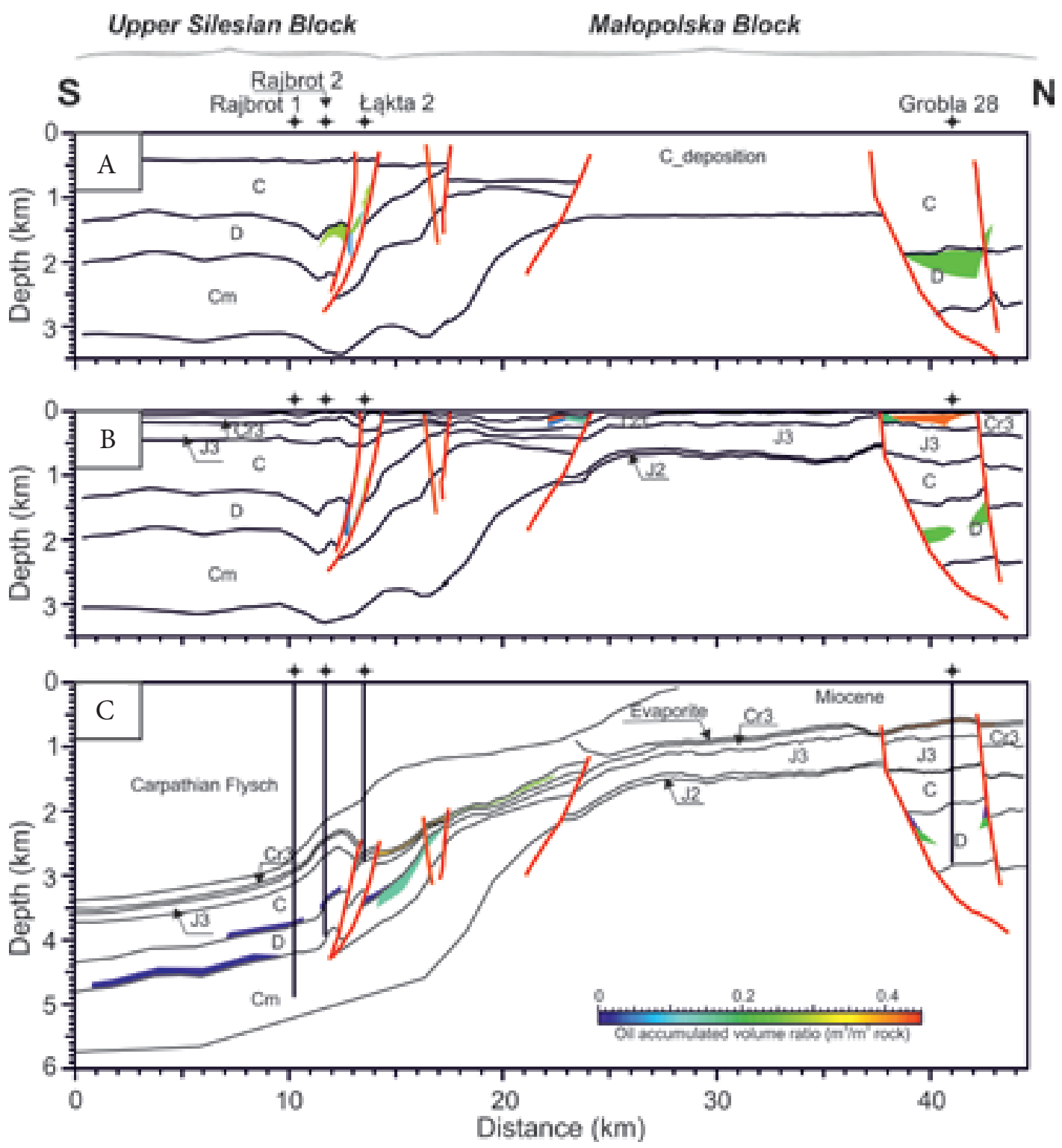

Fig. 11. The volume of the oil accumulation along the A-A'cross-section after the Lower Carboniferous deposition (A), in the beginning of the Miocene sedimentation (B) and at present (C). For abbreviations see Figure 10 
As was mentioned above, the migration paths were made of faults. The Carpathian overthrust caused the change of pressure and tectonic conditions, and enabled migration along faults to the reservoir rocks of the Upper Jurassic and Upper Cretaceous. Two accumulations can be observed along the A-A' cross-section (Figs 11C, 12C).

First, the Łąkta gas field in the Upper Silesian Block located in a tectonic uplift position, connected with regional dislocation. In the Łąkta 2 region, along the A-A' cross-section, the accumulation in the Upper Jurassic and in the Upper Cretaceous was observed mainly in the anticlinal structures around the faults. Hydrocarbons also accumulated in the Devonian, but it is very probable, that those hydrocarbons had migrated in a perpendicular direction to the cross-section plane (Figs 11A, B, 12A, B). The structural maps of the Jurassic and Cretaceous strata and the map of range of the Łąkta field confirmed this theory (Karnkowski 1999a, Florek et al. 2006, Myśliwiec et al. 2006, Buła \& Habryn eds. 2008). The volume of oil accumulated in the Mesozoic reservoir in the Upper Silesian Block ranged from $0.2 \mathrm{~m}^{3} / \mathrm{m}^{3}$ rock, in the Upper Jurassic, to $0.4 \mathrm{~m}^{3} / \mathrm{m}^{3}$ rock, in the Upper Cretaceous (Fig. 11C). The volume of gas amounted to $0.04 \mathrm{~m}^{3} / \mathrm{m}^{3}$ rock (Fig. 12C).

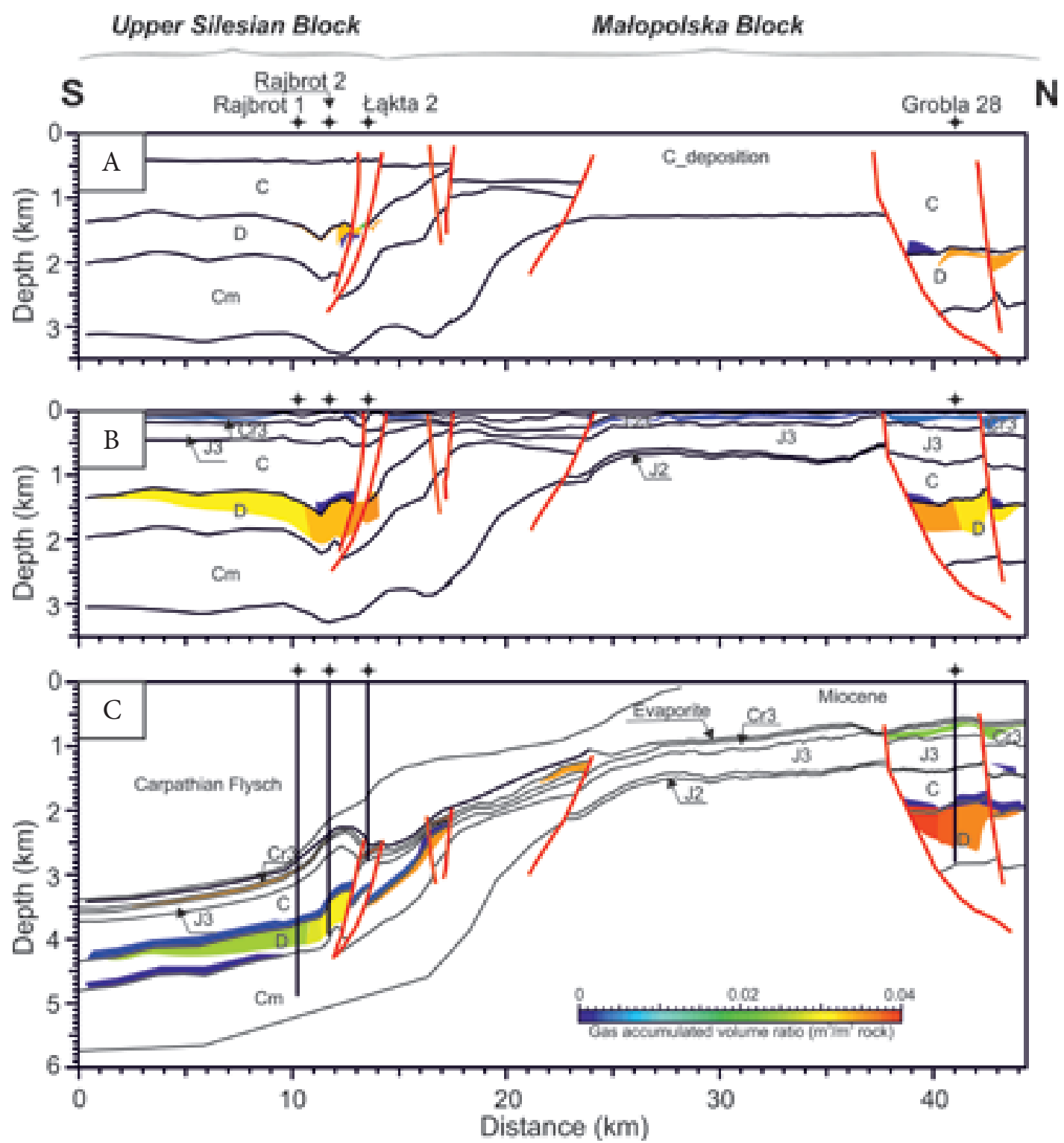

Fig. 12. The volume of the gas accumulation along the A-A'cross-section after the Lower Carboniferous deposition (A), in the beginning of the Miocene sedimentation (B) and at present (C). For abbreviations see Figure 10 
The second accumulation, in the Grobla oil field, was located in the Małopolska Block. The hydrocarbons were accumulated in a set of complicated traps of structural-stratigraphic types (the Oxfordian carbonates) and stratigraphic types (the pinching out of the Cenomanian sandstones) (Myśliwiec et al. 2006). The 2-D modelling along the A-A' cross-section pointed out that the migration started during the Eocene and filled the Jurassic and Cretaceous reservoir successively (Figs $11 \mathrm{~A}, \mathrm{~B}, 12 \mathrm{~A}, \mathrm{~B})$. The analyzed cross-section was located in the western margin of the Grobla oil field, where gas and oil dominated, as the main oil accumulations were located in the eastern part of that oil field (Karnkowski 1999a, Myśliwiec et al. 2006). The Grobla field was terminated from the southern and northern sides by a system of faults, and the western boundary was defined by pinching out of the Cenomanian reservoir rocks on the flanks of the Jurassic elevated structure. The volume of oil accumulation ranged up to $0.45 \mathrm{~m}^{3} / \mathrm{m}^{3}$ rock, and the gas accumulation volume did not exceed $0.025 \mathrm{~m}^{3} / \mathrm{m}^{3}$ rock (Figs 11C, 12C).

\section{CONCLUSIONS}

From the Outer Carpathian sequence in the analysed area, the Menilite Shales, as well as Inoceramian, Rdzawka, Sub-Grybów and Krosno Beds of the Dukla Unit were capable of generating hydrocarbons. In the Palaeozoic-Mesozoic strata of the Upper Silesian Block, the Middle Jurassic strata had the best hydrocarbon potential, but they were too immature to generate liquid hydrocarbons. The Lower Carboniferous strata were indicated as the most probable source rocks from that whole sequence. In the Carpathian Foredeep basement, the most perspective source rocks were carbonates and clastic facies of Devonian and Early Carboniferous age.

The isotopic and biomarker investigations revealed that Menilite Shales deposited in the Dukla Unit sequence had generated oils accumulated in the Carpathian sequence and, probably, condensate also accumulated in the Upper Jurassic carbonates of the Łąkta deposit. Oil from the Grobla deposit was generated most probably from the Middle and Upper Devonian and Lower Carboniferous carbonates.
Petroleum modelling in the Limanowa-Grobla area indicated that the Devonian carbonates were the best source rocks for hydrocarbon generation. The maturity of the Devonian source rock acquired a late phase of the "oil window", even reaching a "gas window" in the Upper Silesian Block. The maturity of Carboniferous source rock did not exceed $1.0 \% R_{o}$. Generation of hydrocarbons started in the late Carboniferous, but the main stage of that process took place in the late Neogene, during Miocene deposition in the Małopolska Block and during the Carpathian overthrust in the Upper Silesian Block. The amount of generated hydrocarbons from the Devonian source rock maximally reached $420 \mathrm{mg} / \mathrm{g}$ TOC. The volume of generated oil from the Carboniferous source horizon did not exceed $220 \mathrm{mg} / \mathrm{g}$ TOC.

The petroleum expulsion process occurred only from the Devonian source rock. The highest volume of expelled hydrocarbons was noticed in the Małopolska Block, where it ranged up to 0.024 $\mathrm{m}^{3} / \mathrm{m}^{3}$ rock. The accumulation of hydrocarbons in the reservoir took place almost exclusively during the Carpathian overthrusting. In the Limanowa-Grobla region, the Upper Jurassic carbonates and the Upper Cretaceous sandstones were characterized as the best reservoirs. Veritcal migration connected with intensive fault systems moved the hydrocarbon mass to the Upper Jurassic carbonates and the Upper Cretaceous sandstones. The hydrocarbons accumulation varied from $0.475 \mathrm{~m}^{3} / \mathrm{m}^{3}$ rock in Małopolska Block (Grobla deposit), to $0.4 \mathrm{~m}^{3} / \mathrm{m}^{3}$ rock in the Upper Silesian Block (Łąkta deposit).

Summing up, it was found that the source of the Mesozoic oil and gas fields in the Limanowa-Grobla area were the Devonian source rocks, confirmed by oil-source rocks correlation. Only in the Łąkta field, the presence of the Outer Carpathian kerogen was observed, which can suggest the possibly of mixing the hydrocarbons from the basement of the Carpathian Foredeep and from the Carpathian flysch in that accumulation. The generation process was strictly connected with the Miocene deposit and Carpathian overthrusting. The migration and accumulation processes occurred during the Carpathian overthrusting and caused the hydrocarbons to be expelled from the 
Upper Palaeozoic strata and to move to the structural and stratigraphic Upper Jurassic and Upper Cretaceous traps, in the tectonic blocks.

The research has been financially supported by the Ministry of Science and Higher Education research project No. UKRAINA/193/2006 and carried out at the AGH University of Science and Technology in Kraków and Polish Geological Institute in Warsaw. The authors would like to thank dr Z. Buła and R. Habryn from the Upper Silesian Branch of Polish Geological Institute for many helpful guidelines about the geological evolution of the study area. The seismic interpretation was made by Dr. Piotr Krzywiec from the Institute of Geological Sciences in Warsaw. The time-depth transformation of seismic interpretation was carried by Prof. K. Pietsch and Dr. Paweł Marzec from AGH University of Science and Technology, Faculty of Geology, Geophysics and Environmental Protection.

\section{REFERENCES}

Belka Z., 1993a. Remarks on thermal maturity level in the subsurface of the Upper Silesian Coal Basin. Acta Geologica Polonica, 43, 95-101.

Belka Z., 1993b. Thermal and burial history of the Cracow-Silesia region (southern Poland) assessed by conodont CAI analysis. Tectonophysics, 227, 161-190.

Bessereau G., Roure F., Kotarba M., Kuśmierek J. \& Strzetelski W., 1996. Structure and hydrocarbon habitat of the Polish Carpathians. [in:] Ziegler P.A. \& Horvath F. (eds.), Peri-Tethys Memoir 2: Structure and Prospects Alpine Basins and Forelands, Mémories Museum National History Naturelle, 170, 343-373.

BMRM 2006. BasinMod Reference Manual. Platte River Association, Boulder, Colorado.

Buła Z., 1994. Problemy stratygrafii i wykształcenia osadów starszego paleozoiku północno-wschodniego obrzeżenia GZW. [in:] Paleozoik pótnocno-wschodniego obrzeżenia Górnośląskiego Zagłębia Węglowego: przewodnik LXV Zjazdu Polskiego Towarzystwa Geologicznego, Sosnowiec, 22-24 września 1994, Prace Naukowe Uniwersytetu Śląskiego w Katowicach, 1431, Wyd. UŚ, Katowice, 31-57.

Buła Z., 2000. Dolny paleozoik Górnego Śląska i zachodniej Małopolski. Prace Państwowego Instytutu Geologicznego, 171, PIG, Warszawa.

Buła Z. \& Habryn R. (red.), 2008. Atlas geologiczno-strukturalny paleozoicznego podłoża Karpat zewnętrznych i zapadliska przedkarpackiego. Państwowy Instytut Geologiczny, Warszawa.

Buła Z. \& Habryn R., 2011. Precambrian and Palaeozoic basement of the Carpathian Foredeep and adjacent the Outer Carpathians (SE Poland and SW Ukraine). Annales Societatis Geologorum Poloniae, 81, 3, 221-239.
Buła Z. \& Jachowicz M., 1996. The Lower Paleozoic sediments in the Upper Silesian Block. Geological Quarterly, 40, 299-336.

Buła Z. \& Krieger W., 2004. Charakterystyka utworów karbonu $\mathrm{w}$ południowej części bloku górnośląskiego. [in:] Kotarba, M.J. (red.), Możliwości generowania węglowodorów w skałach karbonu w południowej części bloku górnoślaskiego i małopolskiego, Towarzystwo Badania Przemian Środowiska "Geosfera", Wydawnictwo Naukowe "Akapit”, Kraków, 15-24 [with English summary].

Buła Z., Jachowicz M. \& Żaba J., 1997. Principal characteristics of the Upper Silesian Block and Małopolska Block border zone (Southern Poland). Geological Magazine, $134,5,669-677$.

Buła Z., Habryn R., Krieger W., Kurek S., Markowiak M. \& Woźniak P., 2002. Atlas map geologicznych paleozoiku bez permu w strefie kontaktu bloków górnoślaskiego i małopolskiego. Państwowy Instytut Geologiczny, Warszawa.

Espitalié J., Deroo G. \& Marquis F., 1985. La pyrolyse Rock Eval et ses applications. Revue de Institut Francais $d u \mathrm{Pe}$ trole, 40, 6, 755-784.

Florek R., Gliniak P. \& Zacharski J., 2006. Nowe spojrzenie na strefę nasuwczą Łąkty w rejonie Łapanów - Tymowa. Nafta-Gaz, 62, 12, 647-654 [with English summary].

Haven H.L. ten, Lafargue E. \& Kotarba M., 1993. Oil/oil and oil/source rock correlations in the Carpathian Foredeep and Overthrust, south-east Poland. Organic Geochemistry, 20, 935-959.

Jachowicz M \& Buła Z. (red.), 2010. Prekambr i paleozoik regionu krakowskiego: model budowy geologicznej, jego aspekt utylitarny: konferencja naukowa Kraków, 19 listopada, 2010: materiaty konferencyjne. Państwowy Instytut Geologiczny - Państwowy Instytut Badawczy, Warszawa.

Jawor E. \& Baran U., 2004. Geological setting and characteristics of Carboniferous strata in the southern part of the Małopolska block. [in:] Kotarba M.J. (red.), Możliwości generowania weglowodorów w skałach karbonu w południowej części bloku górnośląskiego i małopolskiego, Towarzystwo Badania Przemian Środowiska "Geosfera", Wydawnictwo Naukowe "Akapit”, Kraków, 25-48 [with English summary].

Jurkiewicz H. \& Szczerba A., 1976. Wyniki badań termicznych centralnej części niecki miechowskiej i przyległego obszaru Gór Świętokrzyskich. Biuletyn Instytutu Geologicznego, 296, 129-161.

Karnkowski P., 1999a. Oil and gas deposits in Poland. Geosynoptics Society "Geos", AGH University of Science and Technology, Cracow.

Karnkowski P. H., 1999b. Origin and evolution of the Polish Rotliegend Basin. Polish Geological Institute Special Papers, 3, Polish Geological Institute, Warszawa.

Karwasiecka M., 2001. Pole cieplne Górnośląskiego Zagłębia Węglowego. [in:] Materiały Międzynarodowej Konferencji Naukowej „Energia geotermalna w kopalniach podziemnych": Ustroń, 21-23 listopada 2001 r., 41-49 [with English summary].

Karwasiecka M. \& Bruszewska B., 1997. Pole cieplne na obszarze Polski. Centralne Archiwum Geologiczne, Państwowy Instytut Geologiczny, Warszawa. 
Kosakowski P., Więcław D. \& Kotarba M. J., 2009. Charakterystyka macierzystości wybranych utworów fliszowych w przygranicznej strefie polskich Karpat Zewnętrznych. Geologia: kwartalnik Akademii Górniczo-Hutniczej im. Stanisława Staszica w Krakowie, 35, 4/1, 155-190 [with English abstract].

Kosakowski P., Więcław D., Kotarba M. J. \& Kowalski A. 2012. Hydrocarbon potential of the Mesozoic strata between Kraków and Rzeszów (SE Poland). Geological Quarterly, 56, 139-152.

Kotarba M., 2012. Origin of natural gases in the Paleozoic-Mesozoic basement of the Polish Carpathian Foredeep. Geologica Carpathica, 63, 307-318.

Kotarba M.J. \& Koltun Y.V., 2006. The origin and habitat of hydrocarbons of the Polish and Ukrainian Parts of the Carpathian Province. [in:] Golonka J. \& Picha F.J. (eds), The Carpathians and their foreland: geology and hydrocarbon resources, American Association of Petroleum Geologists Memoir, 84, 395-442.

Kotarba M.J., Wagner M., Więcław D., Kosakowski P. \& Kowalski A., 2001. Hydrocarbon potential and geochemical characteristics of organic matter in the Tarnawa 1 borehole section. [in:] Matyja H. (red.), Paleozoik podłoża centralnej części polskich Karpat zewnętrznych (rejon Liplas - Tarnawa), Prace Państwowego Instytutu Geologicznego, 174, PIG, Warszawa, 161-172 [with English summary].

Kotarba M.J., Więcław D., Kosakowski P., Zacharski J. \& Kowalski A., 2003. Ocena macierzystości i potencjału naftowego utworów jury środkowej. Przegląd Geologiczny, 51, 12, 1031-1040 [with English summary].

Kotarba M.J., Więcław D., Kosakowski P. \& Kowalski A., 2004a. Geochemical characteristics of organic matter within Carboniferous strata in the southern part of the Upper Silesian block. [in:] Kotarba M.J. (red.), Możliwości generowania węglowodorów w skałach karbonu w południowej części bloku górnoślaskiego i małopolskiego, Towarzystwo Badania Przemian Środowiska "Geosfera", Wydawnictwo Naukowe "Akapit", Kraków, 49-70 [with English summary].

Kotarba M.J., Więcław D., Kosakowski P. \& Kowalski A., 2004b. Geochemical characteristics of organic matter within Carboniferous strata in the southern part of the Małopolska block. [in:] Kotarba M.J. (red.), Możliwości generowania węglowodorów $w$ skałach karbonu $w$ południowej części bloku górnoślaskiego i małopolskiego, Towarzystwo Badania Przemian Środowiska "Geosfera", Wydawnictwo Naukowe "Akapit", Kraków, 71-86 [with English summary].

Kotarba M. J., Kosakowski P. \& Burzewski W., 2004c. Hydrocarbon generation and expulsion processes based on one dimensional numerical modelling and generation potential of Carboniferous strata in the southern part of the Upper Silesian and Małopolska block. [in:] Kotarba M.J. (red.), Możliwości generowania węglowodorów w skałach karbonu w południowej części bloku górnoślaskiego i małopolskiego, Towarzystwo Badania Przemian Środowiska "Geosfera", Wydawnictwo Naukowe "Akapit”, Kraków, 87-116 [with English summary].

Kotarba M.J., Więcław D., Koltun Y.V., Marynowski L., Kuśmierek J. \& Dudok I.V., 2007. Organic geochemical study and genetic correlation of natural gas, oil and Menilite source rocks in the area between San and Stryi rivers (Polish and Ukrainian Carpathians). Organic Geochemistry, 38, 1431-1456.

Kotarba M.J., Więcław D., Kosakowski P., Wróbel M., Matyszkiewicz J., Buła Z., Krajewski M., Koltun Y.V. \& Tarkowski J., 2011. Petroleum systems in the PalaeozoicMesozoic basement of the Polish and Ukrainian Carpathian Foredeep. Annales Societatis Geologorum Poloniae, 81, 487-522.

Kotarba M.J., Więcław D., Dziadzio P., Kowalski A., Bilkiewicz E. \& Kosakowski P., 2013. Organic geochemical study of source rocks and natural gas and their genetic correlation in the central part of the Polish Outer Carpathians. Marine and Petroleum Geology, 45, 106-120.

Kotarba M.J., Więcław D., Dziadzio P., Kowalski A., Kosakowski P. \& Bilkiewicz E., 2014. Organic geochemical study of source rocks and natural gas and their genetic correlation in the eastern part of the Polish Outer Carpathians and Palaeozoic-Mesozoic basement. Marine and Petroleum Geology, 56, 97-122.

Kotas A., 1972. Osady morskie karbonu górnego i ich przejście w utwory produktywne Górnośląskiego Zagłębia Węglowego. [in:] Karbon Górnośląskiego Zagłębia Węglowego, Prace Instytutu Geologicznego, 61, 279-328.

Kotas A., 1982. Zarys budowy geologicznej Górnośląskiego Zagłębia Węglowego. [in:] Przewodnik 54 Zjazdu Polskiego Towarzystwa Geologicznego, Sosnowiec, 23-25. IX.1982, Wydział Geologii, Warszawa, 45-72.

Kotas A., 1985. Structural evolution of the Upper Coal Basin (Poland). [in] 10 $0^{\text {th }}$ International Carboniferous Congress, Madrid 1983, C. R., 3, 459-469.

Krajewski M., Matyszkiewicz J., Król K. \& Olszwska B., 2011. Facies and sedimentation of the Upper Jurassic-Lower Cretaceous deposits of the Carpathian Foredeep in the Kraków-Rzeszów area, southern Poland. Annales Societatis Geologorum Poloniae, 81, 269-290.

Majorowicz J., 1984. Problems of tectonic interpretation of geothermal field distribution in the platform areas of Poland. Publications of the Institute of Geophysics, Polish Academy of Sciences, A-13 (160), 149-166.

Majorowicz J. \& Plewa S., 1979. Study of heat flow in Poland with special regard to tectonophysical problems. [in:] Cermak V. \& Rybach L. (eds.), Terrestial Heat Flow in Europe, Springer-Verlag, Berlin, 240-251.

Moryc W., 2006. Budowa geologiczna podłoża miocenu w rejonie Kraków-Pilzno. Część 2. Perm I mezozoik. Nafta-Gaz, 6, 263-282 [with English summary].

Myśliwiec M., Borys Z., Bosak B., Liszka B., Madej K., Maksym A., Oleszkiewicz K., Pietrusiak M., Plezia B., Staryszak G., Świętnicka G., Zielińska C., Zychowicz K., Gliniak P., Florek R., Zacharski J., Urbaniec A., Górka A., Karnkowski P. \& Karnkowski P.H., 2006. Hydrocarbon resources of the Polish Carpathian Foredeep: reservoirs, traps, and selected hydrocarbon fields. [in:] Golonka J. \& Picha F. J. (eds), The Carpathians and Their Foreland: Geology and Hydrocarbon Resources, American Association of Petroleum Geologists Memoir, 84, 351-393.

Narkiewicz M., 2002. Ordovician through earliest Devonian development of the Holy Cross Mts. (Poland): constraints from subsidence analysis and thermal maturity data. Geological Quarterly, 46, 255-266. 
Narkiewicz M., 2007. Development and inversion of Devonian and Carboniferous basins in the eastern part of the Variscan foreland (Poland). Geological Quarterly, 51, 231-256.

Narkiewicz M., Resak M., Littke R. \& Marynowski L., 2010. New constraints on the Middle Palaeozoic to Cenozoic burial and thermal history of the Holy Cross Mts. (Central Poland): results from numerical modelling. Geologica Acta, 8, 189-205.

Obermajer M., Fowler M.G. \& Snowdon L.R., 1999. Depositional environment and oil generation in Ordovician source rocks from southwestern Ontario, Canada: organic geochemical and petrological approach. American Association of Petroleum Geologists Bulletin, 83, 9, 1426-1453.

Peters K.E. \& Cassa M.R., 1994. Applied source rock geochemistry. [in:] Magoon L.B. \& Dow W.G. (eds.), The Petroleum System - from source to trap, American Association of Petroleum Geologists Memoir, 60, 93-120.

Plewa S., 1994. Rozkład parametrów geotermalnych na obszarze Polski. Wyd. Centrum Podstawowych Problemów Gospodarki Surowcami Mineralnymi i Energią PAN, Kraków.

Poprawa P., 2006a. Neoproterozoic break-up of the supercontinent Rodinia/Pannotia recorded by development of sedimentary basins at the western slope of Baltica. [in:] Matyja H. \& Poprawa P. (red.), Ewolucja facjalna, tektoniczna $i$ termiczna pomorskiego segmentu szwu transeuropejskiego oraz obszarów przyległych, Prace Państwowego Instytutu Geologicznego, 186, Państwowy Instytut Geologiczny, Warszawa, 165-188 [with English summary].

Poprawa P., 2006b. Development of the Caledonian collision zone along the western margin of Baltica and its relation to the foreland basin. [in:] Matyja H. \& Poprawa P. (red.), Ewolucja facjalna, tektoniczna i termiczna pomorskiego segmentu szwu transeuropejskiego oraz obszarów przyległych, Prace Państwowego Instytutu Geologicznego, 186, Państwowy Instytut Geologiczny, Warszawa, 189-214 [with English summary].

Poprawa D. \& Nemčok J. (eds), 1989. Geological atlas of the western outer Carpathians and their foreland: scale 1:500 000. Państwowy Instytut Geologiczny, Warszawa.

Rutkowski J., 1972. Osady stefanu Górnośląskiego Zagłębia Węglowego. [in:] Karbon Górnośląskiego Zagłębia Węglowego, Prace - Instytut Geologiczny, 61, Wydawnictwa Geologiczne, Warszawa, 539-552.

Sofer Z., 1984. Stable carbon isotope compositions of crude oils: application to source depositional environments and petroleum alteration. American Association of $\mathrm{Pe}$ troleum Geologists Bulletin, 68, 31-49.

Sweeney J.J. \& Burnham A.K., 1990. Evaluation of a simple model of vitrinite reflectance based on chemical kinetics. American Association of Petroleum Geologists Bulletin, 74, 1559-1570.

Więcław D., 2011: Origin of liquid hydrocarbons in the Miocene strata of the Polish Carpathian Foredeep and its Palaeozoic-Mesozoic basement. Annales Societatis Geologorum Poloniae, 81, 443-458.

Więcław D., Kotarba M. J., Kowalski A. \& Kosakowski P., 2011. Habitat and hydrocarbon potential of the Palaeozoic source rocks in the Kraków-Rzeszów area (SE Poland). Annales Societatis Geologorum Poloniae, 81, 375-394.

Żaba J., 1999. Ewolucja strukturalna utworów dolnopaleozoicznych $w$ strefie granicznej bloków górnośląskiego i małopolskiego. Prace Państwowego Instytutu Geologicznego, 166, Państwowy Instytut Geologiczny, Warszawa [with English summary]. 